\title{
Astrocyte $\mathrm{Na}^{+}$Channels Are Required for Maintenance of $\mathrm{Na}^{+} / \mathrm{K}^{+}$-ATPase Activity
}

\author{
H. Sontheimer, ${ }^{1,2}$ E. Fernandez-Marques, ${ }^{1}$ N. Ullrich, ${ }^{3}$ C. A. Pappas, ${ }^{1}$ and S. G. Waxman ${ }^{1,2}$ \\ ${ }^{1}$ Department of Neurology, Yale University School of Medicine, New Haven, Connecticut 06510, ${ }^{2}$ Neuroscience Research \\ Center, VA Hospital, West Haven, Connecticut 06516, and ${ }^{3}$ interdepartmental Neuroscience Graduate Program, Yale \\ University School of Medicine, New Haven, Connecticut 06510
}

\begin{abstract}
Astrocytes in vitro and in situ have been shown to express voltage-activated ion channels previously thought to be restricted to excitable cells, including voltage-activated $\mathrm{Na}^{+}$, $\mathrm{Ca}^{2+}$, and $\mathrm{K}+$ channels. However, unlike neurons, astrocytes do not generate action potentials, and the functional role of voltage-activated channels in astrocytes has been an enigma. In order to study the function of $\mathrm{Na}^{+}$channels in glial cells, we carried out ion flux measurements, patch-clamp recordings, and ratiometric imaging of $\left[\mathrm{Na}^{+}\right]$, during blockade of $\mathrm{Na}^{+}$channels on rat spinal cord astrocytes cultured for 7-10 d. Acute blockade of astrocyte $\mathrm{Na}^{+}$channels by TTX had multiple effects: (1) TTX reduced, in a dose-dependent manner, $\mathrm{Na}^{+} / \mathrm{K}^{+}$-ATPase activity measured as unidirectional influx of ${ }^{88} \mathrm{Rb}^{+}$; (2) TTX depolarized astrocyte membrane potential at a rate of approximately $1 \mathrm{mV} / \mathrm{min}$; (3) $\operatorname{TTX}(100 \mu \mathrm{M})$ reduced $\left[\mathrm{Na}^{+}\right]_{;}$; and (4) prolonged exposure to micromolar TTX induced astrocyte death. All these effects of TTX could be mimicked by ouabain or strophanthidin, specific blockers of the $\mathrm{Na}^{+} / \mathrm{K}^{+}$-ATPase. The effects of TTX and ouabain (or strophanthidin) were not additive. These results suggest that TTX-blockable $\mathrm{Na}^{+}$channels in glial cells serve functions that do not require their participation in action potential electrogenesis; in particular, we propose that glial $\mathrm{Na}^{+}$channels constitute a "return" pathway for $\mathrm{Na}^{+} / \mathrm{K}^{+}$-ATPase function, which permits $\mathrm{Na}^{+}$ions to enter the cells to maintain $\left[\mathrm{Na}^{+}\right]_{i}$ at concentrations necessary for activity of the $\mathrm{Na}^{+} / \mathrm{K}^{+}-$-ATPase. Since astrocyte $\mathrm{Na}^{+} / \mathrm{K}+-$ ATP. ase is believed to participate in $\left[\mathrm{K}^{+}\right]_{0}$ homeostasis in the CNS, the coupling of $\mathrm{Na}^{+}$flux through voltage-activated $\mathrm{Na}^{+}$ channels to ATPase activity may provide a feedback loop that participates in the regulation of $\mathrm{K}^{+}$ion levels in the extracellular space.
\end{abstract}

[Key words: $\mathrm{Na}^{+} / \mathrm{K}^{+}$-ATPase, $\mathrm{Na}^{+}$channel, TTX, ouabain, patch clamp, fluorescence imaging, cell death, sodium-binding benzofuran isophthalate]

\footnotetext{
Received Feb. 19, 1993; Oct. 5, 1993; revised Oct. 19, 1993

We thank Dr. Mary-Louise Roy for providing DRG neurons, Marion Davis for assisting with SBFI recordings, and Drs. B. R. Ransom and J. Murdoch Ritchie for helpful comments on the manuscript. This work was supported in part by the Medical Research Service, Department of Veterans Affairs, and by grants from the National Institutes of Health and the National Multiple Sclerosis Society. H.S. was supported by a Spinal Cord Research Fellowship from the EPVA.

Correspondence should be addressed to Harald Sontheimer, Ph.D., Department of Neurology, Yale University, School of Medicine, 333 Cedar Street, LCI 704, New Haven, CT 06510.

Copyright (C) 1994 Society for Neuroscience $0270-6474 / 94 / 142464-12 \$ 05.00 / 0$
}

Numerous studies on glial cells in vitro and in situ have demonstrated that astrocytes can express voltage-activated ion channels with features similar to channels expressed in excitable cells (for review, see Barres et al., 1990; Chiu 1991; Ritchie, 1992). While the importance of glial $\mathrm{K}^{+}$channels in controlling $\left[\mathrm{K}^{+}\right]_{\circ}$ homeostasis has been demonstrated in vitro and in situ (Orkand, 1977; Newman, 1984, 1986; Ballanyi et al., 1987), the functional roles of voltage-activated $\mathrm{Ca}^{2+}$ and $\mathrm{Na}^{+}$channels in glial cells are less well understood. Although action potential-like responses mediated by $\mathrm{Ca}^{2+}$ (MacVicar, 1984) or $\mathrm{Na}^{+}$channels (Sontheimer et al., 1992) can be elicited in culturcd astrocytes under certain experimental conditions, most glial cells in vitro (Sontheimer and Waxman, 1992) and in situ (Ransom and Goldring, 1973; Somjen, 1975; Walz and MacVicar, 1988; Sontheimer and Waxman, 1993) lack the ability to fire action potentials. Recent patch-clamp recordings from astrocytes in hippocampal brain slices demonstrated that astrocytes in situ, as previously shown in vitro, can express voltage-activated $\mathrm{Na}$ channels (Sontheimer and Waxman, 1993). Furthermore, astrocytes in situ express $\mathrm{Na}^{+}$channel immunoreactivity (Black et al., 1989), thus decreasing concern that these channels are only seen in cell culture. Nevertheless, these observations have not delineated the functional roles of glial $\mathrm{Na}^{+}$channels.

It is now clear that some subclasses of astrocytes, namely, process-bearing astrocytes (Barres et al., 1988, 1989b; Sontheimer et al., 1991a, 1992), can express TTX-sensitive (TTX-S) $\mathrm{Na}^{+}$channels with kinetic features comparable to channels expressed in most neurons. In contrast, flat, non-process-bearing astrocytes, which typically represent the majority of cells in such cultures ( 95\%), express TTX-resistant (TTX-R) $\mathrm{Na}^{+}$channels (Bevan et al., 1985; Nowak et al., 1987; Sontheimer and Waxman, 1992; Sontheimer et al., 1992) with kinetic features that differ from those of neuronal $\mathrm{Na}^{+}$channels (Barres et al., 1989b; Sontheimer and Waxman, 1992). Recent molccular cloning approaches provide further evidence that these astrocytes may express a unique "glial form" of TTX-R Na+ channel (Gautron et al., 1992), termed Na-g. The functional role of Na-g is not known.

$\mathrm{Na}^{+}$channels, both TTX-S and TTX-R, require large changes in the transmembrane voltage to be fully activated. It is questionable whether glial cells ever experience voltage changes sufficient for voltage-dependent gating of $\mathrm{Na}^{+}$channels, which requires depolarizations in excess of $40 \mathrm{mV}$ in most cells. At least four factors mitigate against action potential electrogenesis in astrocytes, despite the presence of voltage-activated $\mathrm{Na}^{+}$channels. (1) Most glial cells express $\mathrm{Na}^{+}$channels at only low den- 
sities ( $<1$ channel $/ \mu \mathrm{m}^{2}$; Table 1 in Sontheimer, 1992). (2) The high $\mathrm{gK}: \mathrm{gNa}$ ratio of astrocytes retards electrogenesis (Sontheimer et al., 1991b). (3) As a result of coupling to adjacent cells via gap junctions (Connors et al., 1984; Kettenmann and Ransom, 1988; Mobbs et al., 1988; Dermietzel et al., 1991) each astrocyte within the syncytium is "clamped" close to the population potential, inhibiting large depolarizations. (4) In the few astrocytes that express high densities of $\mathrm{Na}^{+}$channels (2-8 channels $/ \mu \mathrm{m}^{2}$; Sontheimer and Waxman, 1992; Sontheimer et al., 1992), most $\mathrm{Na}^{+}$channels are inactivated due to a mismatch between steady-state inactivation and resting potential (Sontheimer and Waxman, 1992).

Given thesc concerns, we set out to investigate whether voltage-activated $\mathrm{Na}^{+}$channels in glial cells could serve functions that do not require their participation in action potential electrogenesis. We chose to study spinal cord astrocytes, which express $\mathrm{Na}^{+}$channels in uniquely high densities in vitro (2-8 channels $/ \mu \mathrm{m}^{2}$ ), about $1-2$ orders of magnitude higher than in other astrocytes (Sontheimer et al., 1992). The data presented here provide evidence that a TTX-inhibitable $\mathrm{Na}^{+}$conductance exists in these astrocytes at their resting potential, and that $\mathrm{Na}^{+}$ ion fluxes mediated by $\mathrm{Na}^{+}$channels are important for operation of the astrocyte $\mathrm{Na}^{+} / \mathrm{K}^{+}$-ATPase. Blockage of this "return pathway" for $\mathrm{Na}^{+}$ions reduces $\left[\mathrm{Na}^{+}\right]_{i}$, and inhibits ATPase activity, and prolonged exposure (30-120 min) leads to cell death, suggesting that the presence of $\mathrm{Na}^{+}$channels is vital for these cells.

\section{Materials and Methods}

\section{Cell cultures}

Astrocytes. Cultures were obtained from neonatal Sprague-Dawley rats as described elsewhere (Black et al., 1993). In brief, rat pups were deeply anesthetized by $\mathrm{CO}_{2}$ narcosis and decapitated. Spinal cords were dissected free from mid-cervical to lower lumbar levels and the meninges removed. The cords werc minced and incubated in an enzyme solution containing Earle's salts, $30 \mathrm{U} / \mathrm{ml}$ papain (Worthington), $0.5 \mathrm{~mm}$ EDTA, and $1.65 \mathrm{~mm} \mathrm{~L}$-cysteine for $30 \mathrm{~min}$ at $37^{\circ} \mathrm{C}$. The tissue was triturated in complete medium [Earle's minimal essential medium containing $10 \%$ fetal bovine serum (Hyclone), penicillin/streptomycin $(500 \mathrm{U} / \mathrm{ml}$ each) and $20 \mathrm{~mm}$ glucose] containing trypsin inhibitor and bovine serum albumin (BSA) (each $1.5 \mathrm{mg} / \mathrm{ml}$ ), and the cell suspension was plated onto polyornithine/laminin-coated $12 \mathrm{~mm}$ circular glass coverslips at a density of $2.5 \times 10^{5} / \mathrm{ml}$. The cells were maintained at $37^{\circ} \mathrm{C}$ in a $5 \%$ $\mathrm{CO}_{2}, 95 \%$ air atmosphere and were fed every second day with complete media.

C6 glioma cells. C6 rat astrocytoma cell lines were purchased from American Type Culture Collection. Cells were grown in Dulbecco's modified Eagle's medium plus $10 \%$ heat-inactivated fetal calf serum (GIBCO). Cells were plated on uncoated $12 \mathrm{~mm}$ glass coverslips and were used for uptake studies $2 \mathbf{d}$ after plating.

$D R G$ neurons. Dorsal root ganglion (DRG) neurons were prepared as previously described (Roy and Narahashi, 1992). In brief, 7-d-old Sprague-Dawley rats were anesthetized with sodium pentobarbital (i.p., $0.4 \mathrm{ml}$ at $3 \mathrm{mg} / \mathrm{ml}$ ). The vertebral column was removed and cut longitudinally, generating two hemisections that were placed in sterile $\mathrm{Ca}^{2+} /$ $\mathrm{Mg}^{2+}$-free phosphate-buffered saline (PBS). The ganglia were isolated from the spinal lumen and incubated for $20 \mathrm{~min}$ in trypsin $(2 \mathrm{mg} / \mathrm{ml}$, $36^{\circ} \mathrm{C}$ ). Cells were rinsed twice with PBS and were mechanically isolated by trituration, and were plated on polylysine-coated $12 \mathrm{~mm}$ glass coverslips.

\section{Cell identification}

Two morphologically distinguishable subtypes of astrocytes (Sontheimer et al., 1992) were used for recordings. (1) Pancake astrocytes are round, non-process-bearing cells with large somata. Their unique morphology makes them easy to identify. (2) Stellate astrocytes have round, generally small somata and extensive processes that are often arborized. These cell types were initially identified immunohistochemically as glial fibrillary acidic protein (GFAP)-positive astrocytes [e.g., as described by Black et al. (1993) and Sontheimer et al. (1991b, 1992)]. A2B5 antibodies failed to distinguish the two subtypes of astrocytes reliably, suggesting that they may differ from the astrocyte lineage in optic nerve (Miller and Szigeti, 1991; Sontheimer et al., 1992; Black et al., 1993). Flux studies were obtained from astrocyte populations grown on glass coverslips or 24-well plates. Those cell populations were used after 7$10 \mathrm{~d}$ in vitro (DIV) and were $>98 \%$ GFAP + astrocytes. They contained approximately $5-10 \%$ astrocytes with stellate, process-bearing morphology and $90-95 \%$ flat, non-process-bearing astrocytes. The time window of $7-10$ DIV was selected for study hecause our previous electrophysiological studies indicated that spinal cord astrocytes express highest densities of $\mathrm{Na}^{+}$channels during this time period (Sontheimer et al., 1992).

\section{Electrophysiology}

Current and voltage recordings were obtained using the whole-cell mode of the patch-clamp technique (Hamill et al., 1981) in both voltage-clamp and current-clamp mode. Patch pipettes were made from thin-walled borosilicate glass (World Precision Instruments, TW150F-40; o.d. 1.5 $\mathrm{mm}$, i.d. $1.2 \mathrm{~mm}$ ). Electrodes were filled with a solution containing, in mM, $\mathrm{KCl}, 145 ; \mathrm{MgCl}_{2}, 1 ; \mathrm{CaCl}_{2}, 0.2 ;$ EGTA, 10; HEPES, $10 ; \mathrm{pH}$ adjusted to 7.4 using Tris. Recordings were made on the stage of an inverted microscope (Nikon Diaphot) equipped with Hoffman modulation contrast optics and epifluorescence. Cells were continuously superfused with bicarbonate-buffered saline solution at room temperature, allowing for rapid $(<20 \mathrm{sec}$ ) exchange of the bath volume. The bath solution contained, in $\mathrm{mM}, \mathrm{NaCl}, 122.6 ; \mathrm{KCl}, 5.0 ; \mathrm{MgSO}_{4}, 1.2 ; \mathrm{CaCl}_{2}, 1.0 ; \mathrm{Na}_{2} \mathrm{HPO}_{4}$, $2.0 ; \mathrm{NaH}_{2} \mathrm{PO}_{4}, 0.4 ; \mathrm{NaHCO}_{3}, 25.0 ; \mathrm{Na}_{2} \mathrm{SO}_{4}, 1.2 ;$ glucose, $10.5 ;$ bubbled with $5: 95 \% \mathrm{CO}_{2}: \mathrm{O}_{2}$. Additional recordings were also obtained in HEPESbuffered solution, and these yielded similar results, but were not included in the analysis.

Current and voltage recordings were obtained using an Axopatch-1D amplifier (Axon Instruments). Voltage signals were low-pass filtered at $1 \mathrm{kHz}$ using an eight-pole Bessel filter (Frequency Devices), and then digitized on line at $1 \mathrm{kHz}$ using a Labmaster TL-125 digitizing board (Axon Instruments) interfaced with an IBM-compatible computer (Gateway 486, Gateway 2000 Inc.). Current signals were filtered at 3 $\mathrm{kHz}$ and digitized at $100 \mathrm{kHz}$ using the above equipment. Cell capacitance was measured as described previously (Sontheimer et al., 1991b). Data acquisition was performed using either AXOTAPE or pCLAMP (AXon Instruments). Data were analyzed using a scientific graphing program (ORIGIN, MicroCal), and slopes of voltage changes were obtained from linear regression analysis. $\mathrm{Na}^{+}$current densities were derived from peak currents by dividing peaks by membrane capacitance. Peak $\mathrm{Na}^{+}$currents were evoked in response to a step from $-110 \mathrm{mV}$ to $-10 \mathrm{mV}$.

\section{${ }^{86} R b^{+}$flux studies}

${ }^{86} \mathrm{Rb}^{+}$was used to measure $\mathrm{Na}^{+} / \mathrm{K}^{+}-\mathrm{ATPase}$ activity. ${ }^{86} \mathrm{Rb}^{+}$ions are taken up by the $\mathrm{Na}^{+} / \mathrm{K}^{+}$-ATPase like $\mathrm{K}^{+}$ions, but have the advantage of a much longer half-life than ${ }^{42} \mathrm{~K}^{+}$(Kimelberg and Mayhew, 1975). Thus, measurement of the unidirectional ouabain-sensitive ${ }^{86} \mathrm{Rb}^{+}$uptake provides a quantitative method for assaying $\mathrm{Na}^{+} / \mathrm{K}^{+}-\mathrm{ATPase}$ activity. Astrocytes used for flux studies were grown in 24-well trays and were used after 7-10 DIV. The growth media were removed by aspiration and the cells were washed three times with a normal balanced salt solution containing, in $\mathrm{mM}, \mathrm{NaCl}, 137 ; \mathrm{KCl}, 5.3 ; \mathrm{MgCl}_{2}, 1 ; \mathrm{CaCl}_{2}$, 3; dextrose, 25; HEPES, 10; pH 7.2. A $0.5 \mathrm{ml}$ aliquot of the same buffer containing $5 \mu \mathrm{Ci}$ of ${ }^{86} \mathrm{Rb}^{+}$was added to each well (at $37^{\circ} \mathrm{C}$ ). Following a 15 min incubation with the isotope, the media were aspirated from each well and cells were washed three times with $0.5 \mathrm{ml}$ of ice-cold 0.29 M mannitol containing $10 \mathrm{~mm}$ Tris nitratc and $0.5 \mathrm{~mm} \mathrm{Ca}\left(\mathrm{NO}_{3}\right)_{2}$ at $\mathrm{pH}$ 7.4. The cell monolayer from each well was then solubilized in $0.5 \mathrm{ml}$ of $1 \mathrm{~N} \mathrm{NaOH}$ at room temperature for $20 \mathrm{~min}$. The cellular content of the isotope was measured by liquid scintillation counting (counted by Cerenkov radiation), and cell protein was determined using the bicinchoninic acid protein assay (Smith et al., 1985) following the modifications described by Goldschmidt and Kimelberg (1989) for cultured cells. Counts were normalized as $\mathrm{dpm} / \mu \mathrm{l} * \mu \mathrm{g}$ protein. ${ }^{86} \mathrm{Rb}^{+}$fluxes were determined in the presence and absence of the following drugs: TTX (100 nм to $100 \mu \mathrm{M}$; Sigma), strophanthidin (1-5 mM; Sigma), ouabain (1-5 mM; Sigma), 4-aminopyridine (4-AP; $2 \mathrm{~mm}$; Sigma), and $\mathrm{Ba}^{2+}(1$ mM; Sigma), and combinations of these drugs. For comparison of experiments under these various conditions, values were normalized to 
their untreated controls, and changes in flux were expressed as percentage of control.

\section{Viability studies}

Cell viability was examined by monitoring the cells' ability to exclude trypan blue $(0.03 \%$; Sigma; procedure as described by Sigma, Biochemicals and Organic Compounds, 1992, pp 1330-1331). Cell counts were also made on sister cultures, paired with the ones used for flux studies, which were cultured and treated identically. For each condition, cells from at least 10 randomly selectcd regions of at lcast threc wclls wcrc counted under phase contrast at $200 \times$ magnification using an Olympus CK2 microscope, and the numbers of viable and nonviable cells were determined in each region. Using this protocol cell viability was assayed for untreated control cells and for cells maintained in the presence of $100 \mathrm{nM}$ to $100 \mu \mathrm{M}$ TTX or 1-5 mM strophanthidin for $0,5,15,60$, and $120 \mathrm{~min}$. To assure that those trypan blue exclusion studies were a valid indication for cell viability, we additionally studied cell viability using a new two-color fluorescence cell viability assay (Molecular Probes, "Live/Dead") that permits the simultaneous determination of live and dead cells with two probes that measure two recognized parameters of cell viability, intracellular esterase activity and plasma membrane integrity (Moore et al., 1990). The concentrations of fluorophores used were ethidium homodimer at $2 \mu \mathrm{M}$ and calcein acetoxymethyl ester (AM) at $1 \mu \mathrm{M}$.

\section{Ratiometric imaging of $\left[\mathrm{Na}^{+}\right]_{\mathrm{i}}$ using $\mathrm{SBFI}$}

Cytosolic free $\mathrm{Na}^{+}$was measured using of a recently developed indicator for $\mathrm{Na}^{+}$, SBFI (sodium-binding benzofuran isophthalate; Harootunian et al., 1989). Astrocytes were cultured as described above but on $24 \times$ $24 \mathrm{~mm}$ square coverslips that doubled as the bottom of a flow-through perfusion chamber. The membrane-permeable acetoxymethyl ester form of SBFI (SBFI/AM; Molecular Probes) was dissolved in dimethyl sulfoxide (DMSO) at a stock concentration of $10 \mathrm{~mm}$. Before introduction to cells the dye was mixed 1:1 with 25\% Pluronic F-127 (Molecular Probes). Final concentration of the dye was $5 \mu \mathrm{M}$, and cells were loaded for $90 \mathrm{~min}$ at room temperature. Recordings were obtained on the stage of a Nikon Diaphot microscope using a commercially available ratiometric imaging setup (Georgia Instruments). Excitation light was provided by a two-channel monochrometer containing separate xenon arc lamps and defraction gradients for both wavelengths used $(340: 385 \mathrm{~nm})$. Excitation light was passed to the cells through a dichroic reflector $(400$ $\mathrm{nm}$ ) and emitted light above $450 \mathrm{~nm}$ was collected. Fluorescence signals were amplified by an image intensifier (GenIISyS) and collected with a CCD camera (CCD72, Dage) interfaced to a frame grabber (Matrox). Custom software controlled both excitation source and collection of images, and mean pixel intensity of cells of interest was stored to disk separately for 340 and $385 \mathrm{~nm}$. To account for fluorescence rundown, the fluorescence ratio 340:385 was used to assay cytosolic free $\mathrm{Na}^{+}$. Cells were continuously perfused at room temperature at a rate of $2 \mathrm{ml} /$ min using the same saline as used for electrophysiology. Full exchange of the bath fluid required $12 \mathrm{sec}$. For calibration of fluorescence signals cells were superfused with saline containing $10 \mathrm{mM} \mathrm{Na}^{+}$with all residual $\mathrm{Na}^{+}$replaced by $N$-methyl-D-glucamine, in the presence of the ionophore gramidicidin D ( $5 \mu \mathrm{M}$ in DMSO). Cells did not tolerate gramidicidin well, and thus our attempts to calibrate them were limited to a single $\mathrm{Na}^{+}$concentration at the end of every experiment. Prior to application of gramidicidin, we applicd a $0 \mathrm{Na}^{+}$bath solution that had been demonstrated to deplete intracellular $\mathrm{Na}^{+}$completely in other cells (Negulescu et al., 1990). Assuming that this represented the maximal effect, we expressed our data as percentage of 340:385 ratio as compared to the same ratio in $0 \mathrm{Na}^{+}$. Our limited attempts to calibrate absolute values assumed that in $0 \mathrm{Na}^{+}$bath solution $\left[\mathrm{Na}^{+}\right]_{i}$ was also close to 0 , and that over the range of $0-15 \mathrm{~mm}$ the $340: 385$ ratio was linear as previously described for gastric cells and lymphocytes (Harootunian et al., 1989; Negulescu et al., 1990). Long-term recordings were not possible for two reasons. (1) We observed a rapid bleach of SBFI dye, which limited the total length of recordings to $20-30 \mathrm{~min}$. (2) TTX had to be applied at high concentrations $(100 \mu \mathrm{M})$ as the $K_{d}$ for $\mathrm{Na}^{+}$channel block in these cells was $1 \mu \mathrm{M}$. The flow rate of our system required $1 \mathrm{mg}$ of TTX for a $10 \mathrm{~min}$ application. Graphing of data was obtained as described for electrophysiology data.

\section{Data analysis and statistics}

Voltage recordings were obtained by on-line digitizing of data as described above. For analysis, these traces were exported to ORIGIN
(MicroCal Inc.), a scientific graphing and data analysis program. Slopes of voltage changes were derived from linear fits, and mean values and standard deviation were derived from the fitted values. Flux studies were analyzed as described above. Mean values of changes in flux rates were determined and graphed to represent mean and SEs. All statistical tests were done using a commercially available statistics program INSTAT (GraphPad Inc.). Whenever two groups of data were compared we used either Student's $t$ test (for data with normal distribution) or the MannWhitney test (Wilcoxon; for non-normal data) and the uncorrected $p$ values of these tests are given. In those events where multiple groups of data were compared we used a one-way analysis of variance (ANOVA) test to determine significance. $P$ values were corrected using the Bonferroni method, and whenever corrected $p$ values were given, this is indicated in the text.

\section{Results}

Astrocytes cultured from rat spinal cord were used to study functional roles of astrocyte $\mathrm{Na}^{+}$channels because these cells can express $\mathrm{Na}^{+}$channels in higher densities than observed in most other glial cells (Sontheimer et al., 1992). Whole-cell $\mathrm{Na}^{+}$ currents in these cells often exceed $5 \mathrm{nA}$ and channel densities have been estimated to be between 2 and 8 channels $/ \mu \mathrm{m}^{2}$ (Sontheimer et al., 1992). These cultures contain two morphologically distinguishable astrocyte subtypes that express $\mathrm{Na}^{+}$channels that differ in their sensitivity to TTX (Sontheimer and Waxman, 1992). Process-bearing stellate astrocytes comprise $\sim 5 \%$ of all cells in these cultures and express TTX-S Na+ channels $\left(K_{d}=5 \mathrm{nM}\right)$ that resemble $\mathrm{Na}^{+}$channels expressed in most excitable cells (Hille, 1992) in terms of their kinetics, steadystate activation and steady-state inactivation. The majority of cclls $(\sim 95 \%)$ arc non-process-bearing pancake astrocytes and these express TTX-R "glial" $\mathrm{Na}^{+}$channels $\left(K_{d}=1 \mu \mathrm{M}\right)$, which differ in their steady-state activation and steady-state inactivation curves from TTX-S channels (Sontheimer and Waxman, 1992).

\section{Effects of TTX on membrane potential}

Using patch-clamp methods (Hamill et al., 1981), whole-cell current-clamp recordings were obtained from both astrocyte types to search for voltage-activated $\mathrm{Na}^{+}$currents. Voltage recordings were then obtained in current-clamp mode (in the absence of any holding currents) to determine whether blockage of $\mathrm{Na}^{+}$channels with TTX influences the cells' resting potential.

In astrocytcs that expressed voltage-activated $\mathrm{Na}^{+}$currents in high densities $(>50 \mathrm{pA} / \mathrm{pF})$, as assessed by their whole-cell currents, application of $1-100 \mu \mathrm{M}$ TTX resulted in an immediate and transient hyperpolarization of the membrane by $3-10 \mathrm{mV}$, bringing the potential closer to the $\mathrm{K}^{+}$equilibrium potential $\left(E_{K}\right.$ $=-84 \mathrm{mV}$ under the imposed ionic conditions; Fig. $1 \mathrm{a}$, arrow). This transient hyperpolarization was followed by a much slower, persistent depolarization that was observed in both stellate and pancake astrocytes. Astrocytes that expressed $\mathrm{Na}^{+}$currents at lower channel densities $(5-30 \mathrm{pA} / \mathrm{pF})$ did not show a transient hyperpolarization upon TTX application, but showed the slow depolarization following exposure to TTX (Fig. 1b). This slow depolarization persisted during continued TTX application with a mean rate of $1.04 \mathrm{mV} / \mathrm{min}(N=9$; $\mathrm{SD} 0.35)$. The depolarization was reversible upon removal of TIX, but only if the membrane had not reached values more positive than $-65 \mathrm{mV}$ (Fig. 1a). If the membrane depolarized beyond this lcvel it continued to "run down" the membrane potential at an accelerated rate even upon termination of TTX (Fig. 1b, arrow).

In contrast, in astrocytes that did not show measurable $\mathrm{Na}^{+}$ currents $\left(I_{\mathrm{Na}}<1 \mathrm{pA} / \mathrm{pF}\right)$, membrane potential was not affected 


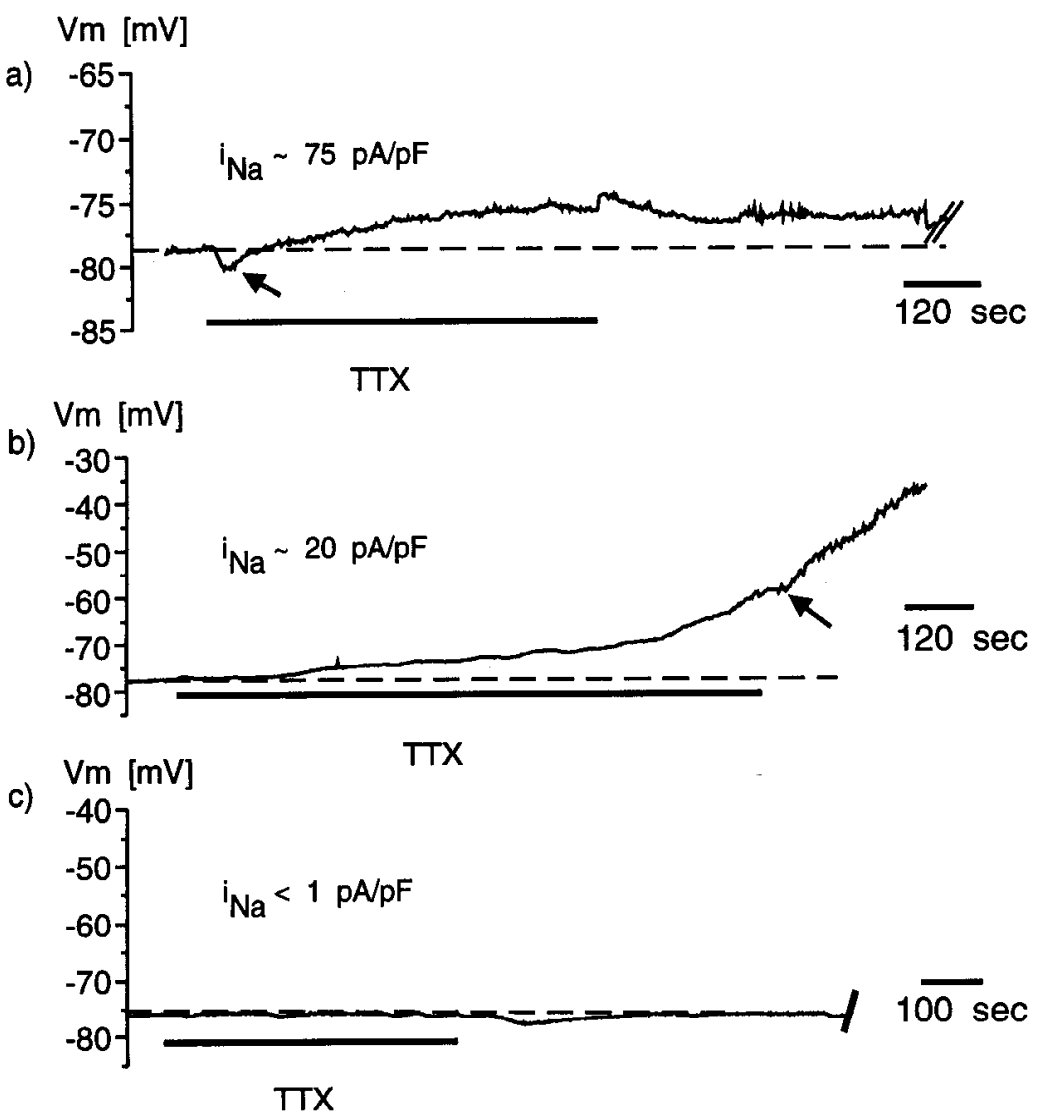

d)

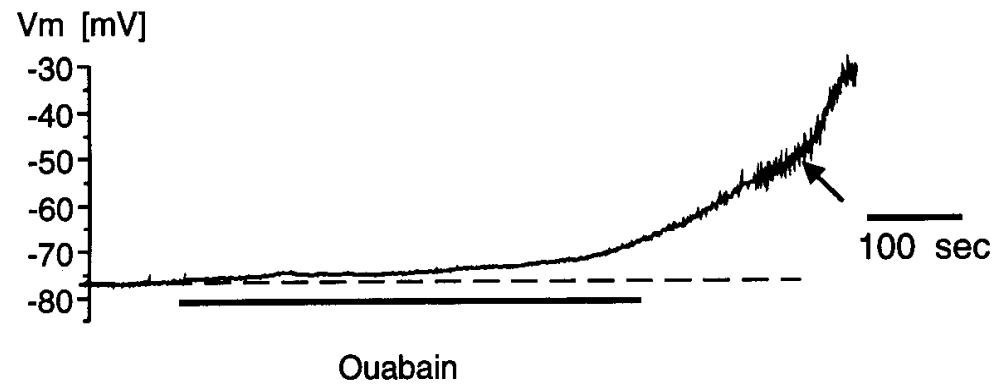

Figure 1. Effects of TTX and ouabain on resting potential of representative cultured spinal cord astrocytes. TTX (1 $\mu \mathrm{M})$ and ouabain (1 $\mathrm{mM})$ were applied for the periods indicated by the horizontal bars. $a$, Example of an astrocyte that had comparably large $\mathrm{Na}^{+}$current density $\left(I_{\mathrm{Na}} \sim 75 \mathrm{pA} / \mathrm{pF}\right)$. In cells with $I_{\mathrm{Na}}$ of $>50 \mathrm{pA} / \mathrm{pF}$, TTX application evoked a transient hyperpolarization (arrow) preceding a prolonged depolarization. $b$, Example of a cell that expressed $\mathrm{Na}^{+}$currents at a lower density of $20 \mathrm{pA} / \mathrm{pF}$. Note that in cells where membrane potential depolarized to levels more positive than $-65 \mathrm{mV}$, rundown continued at accelerated rate ( $a r$ row) after removal of TTX from the bath. $c$, Example of an astrocyte that did not show measurable $\mathrm{Na}^{+}$currents. Potential is unchanged during application of TTX. $d$, Application of ouabain to a representative astrocyte. Ouabain-induced depolarization was similar in time course and magnitude to TTXinduced depolarization $(b)$. by application of TTX (1-100 $\mu \mathrm{M}$; Fig. 1c). Stable recordings could be obtained for up to 90 min during which membrane potential did not change in these cells.

The transient hyperpolarization following TTX application (Fig. $\mathrm{la}$ ), observed in cells that expressed $\mathrm{Na}^{+}$channels in high densities, suggests that a significant resting $\mathrm{Na}^{+}$conductance cxists, large enough to contribute a few millivolts to the cells' resting potential. Indeed, steady-state $\mathrm{Na}^{+}$current activation $\left(m_{\infty}\right)$ and steady-state $\mathrm{Na}^{+}$current inactivation $\left(h_{\infty}\right)$ kinetics in these astrocytes show overlapping regions where both $m_{\infty}$ and $h_{\infty}$ are $>0$, close to the cells' resting potential (Sontheimer and Waxman, 1992), suggesting the existence of a resting $\mathrm{Na}^{+}$conductance. These "window currents" suffice to explain the hyperpolarization that we observed, but do not account for the slow depolarization observed in $\mathrm{Na}^{+}$current-expressing astrocytes. The slow time course of the depolarization suggested that it could be mediated by an ion transporter rather than by ion channels.

To determine whether changes in $\mathrm{Na}^{+} / \mathrm{K}^{+}$-ATPase activity could reproduce this depolarization, we examined the effects of ouabain, a specific inhibitor of the $\mathrm{Na}^{+} / \mathrm{K}^{+}$-ATPase, on these astrocytes. As shown in Figure $1 d$, ouabain produced a slow depolarization that was qualitatively similar to the one observed following application of TTX in all cells studied. The mean rate of this depolarization was $1.5 \mathrm{mV} / \mathrm{min}(\mathrm{SD} 0.74, N=5)$, similar to the rate of depolarization induced by TTX. As with TTX, when the membrane depolarization reached levels more positive than $-65 \mathrm{mV}$, rundown of the membrane potential continued at an accelerated rate. The similarity in the effects of TTX and ouabain suggested that the depolarizations induced by these drugs might be mediated by the same pathway, namely, by changes in the activity of the $\mathrm{Na}^{+} / \mathrm{K}^{+}-\mathrm{ATPase}$.

${ }^{86} \mathrm{R} b^{+}$influx as a measure of $\mathrm{Na}^{+} / \mathrm{K}^{+}-$ATPase activity

To test the possibility that blockage of $\mathrm{Na}^{+}$channels may have altered ATPase activity, we assaycd $\mathrm{Na}^{+} / \mathrm{K}^{+}$-ATPase activity more directly, by measuring unidirectional influx of ${ }^{86} \mathrm{Rb}^{+}$, which is taken up by $\mathrm{Na}^{+} / \mathrm{K}^{+}$-ATPase in the same manner as $\mathrm{K}^{+}$ (Kimelberg and Mayhew, 1975) but has a significantly longer half-life than ${ }^{42} \mathrm{~K}^{+}$. Thus, unidirectional flux rates of ${ }^{86} \mathrm{Rb}^{+}$can 


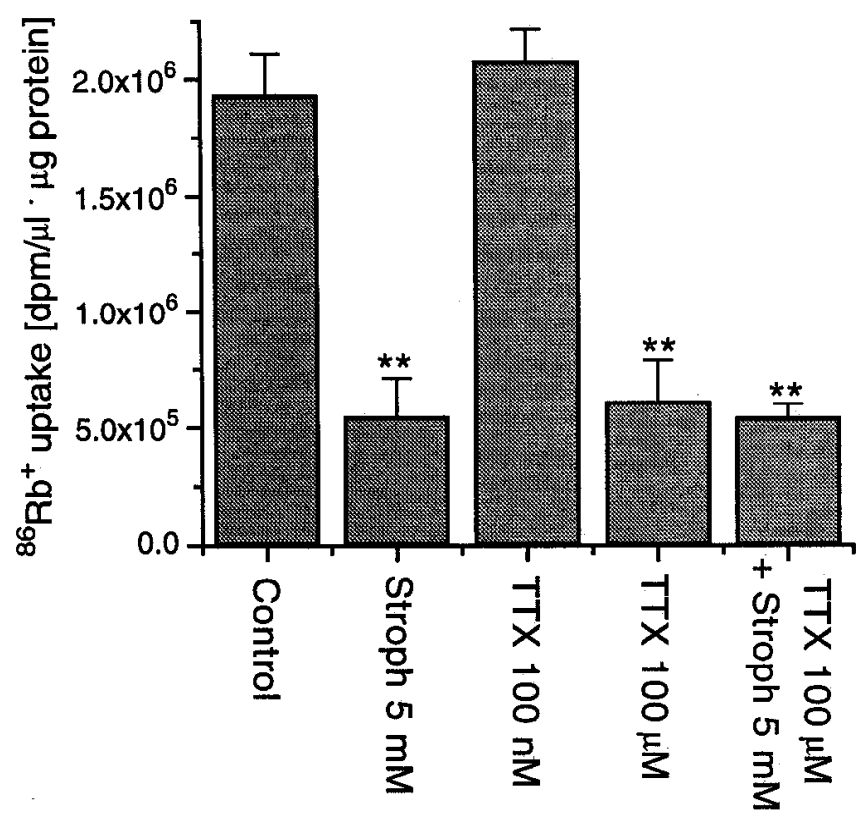

Figure 2. Representative experiment showing alteration of $\mathrm{Na}^{+} / \mathrm{K}^{+}$ATPase activity by TTX and strophanthidin measured as unidirectional influx of ${ }^{86} \mathrm{Rb}^{+} .{ }^{86} \mathrm{Rb}^{+}$uptake was determined in spinal cord astrocytes following $5 \mathrm{~min}$ incubation with the isotope in combination with TTX, strophanthidin or TTX and strophanthidin in combination at the concentrations indicated (significant changes in flux: ${ }^{* *}, p<0.01$, Bonferroni $p$ values from ANOVA). Strophanthidin, $100 \mu \mathrm{M}$ TTX, as well as both drugs in combination showed similar reduction in ${ }^{86} \mathbf{R b}^{+}$uptake, while $100 \mathrm{nM}$ TTX did not alter ${ }^{86} \mathrm{Rb}^{+}$uptake significantly.

serve as a measure of $\mathrm{Na}^{+} / \mathrm{K}^{+}$-ATPase activity. ${ }^{86} \mathrm{Rb}^{+}$can enter cells via at least two pathways: (1) by diffusion through $\mathrm{K}^{+}$ channels, and (2) by active transport through the $\mathrm{Na}^{+} / \mathrm{K}^{+}-\mathrm{ATP}-$ ase. ${ }^{86} \mathrm{Rb}^{+}$flux rates were determined in untreated astrocytes and compared to flux rates in astrocytes exposed to either TTX (100 nM to $100 \mu \mathrm{M}$; Figs. 2, 3), ouabain (1-5 mM; Fig. 3), strophanthidin (1-5 mM; Figs. 2, 3), or TTX in combination with either ouabain or strophanthidin (Figs. 2, 3) for $15 \mathrm{~min}$. The results from a representative experiment are summarized in Figure 2.

Strophanthidin reduced ${ }^{86} \mathrm{Rb}^{+}$fluxes in a dose-dependent manner, with the most pronounced inhibition, up to $80 \%$, observed at $5 \mathrm{~mm}$ concentration. The low sensitivity of the astrocyte $\mathrm{Na}^{+} / \mathrm{K}^{+}$-ATPase is in agreement with previous observations (Sweadner, 1979) demonstrating that astrocytes express an isoform of the $\mathrm{Na}^{+} / \mathrm{K}^{+}$-ATPase that is relatively resistant to both ouabain and strophanthidin $\left(K_{d}\right.$ of $1 \mathrm{~mm}$ for strophanthidin (Sweadner, 1979). We studied in more detail the dose dependence of $\mathrm{Na}^{+} / \mathrm{K}^{+}$-ATPase inhibition (measured by ${ }^{86} \mathrm{Rb}^{+}$ flux) by ouabain, strophanthidin, and TTX; mean values resulting from these experiments were plotted in Figure 3. Ouabain inhibition of ${ }^{86} \mathrm{Rb}^{+}$influx ranged from $87 \%$ to $32 \%$ of control ( $2 \mathrm{~mm}$ ouabain: influx decreased to $54.9 \pm 4.4 \%, N=$ 21; 5 mM ouabain: $37.6 \pm 8.5 \%, N=6$ ) and was similar to inhibition by strophanthidin ( $5 \mathrm{~mm}$ : $37.4 \pm 5.4 \%, N=12$ ).

As shown in Figurcs 2 and 3, TTX also inhibited ${ }^{86} \mathrm{Rb}^{+}$influx in a manner similar to strophanthidin and ouabain. TTX reduced ${ }^{86} \mathrm{Rb}^{+}$flux in a dose-dependent manner, with maximal inhibition at $100 \mu \mathrm{M}$ TTX (the highest concentration studied; Fig. 3) that resulted in a reduction of ${ }^{86} \mathrm{Rb}^{+}$fluxes by $61 \%$ $( \pm 5.2 \%, N=48 ; p<0.001)$. This was almost indistinguishable

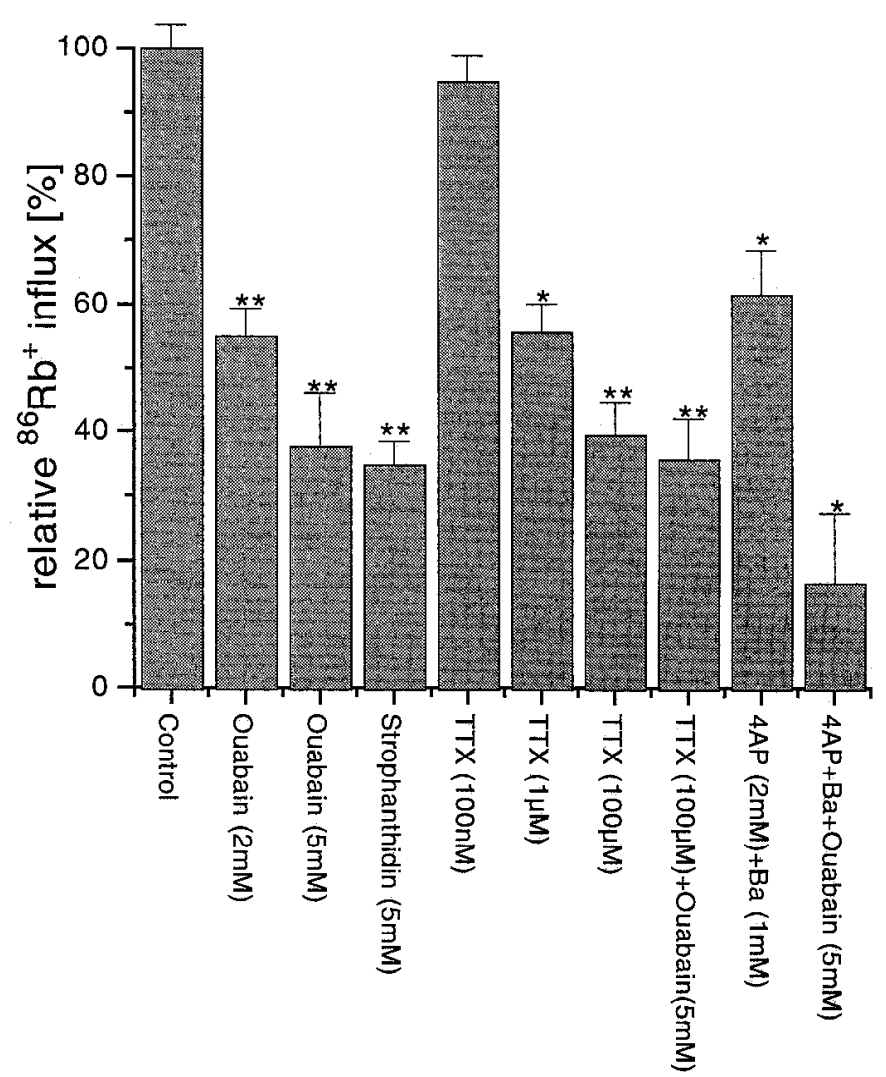

Figure 3. Dosc-dependent reduction of ${ }^{86} \mathrm{Rb}^{+}$uptake by ouabain and TTX. The effects of ouabain and strophanthidin on ${ }^{86} \mathrm{Rb}^{+}$uptake were compared, at different concentrations, to effects of TTX or TTX in combination with ouabain. To determine the relative contribution of $\mathrm{K}^{+}$channel-mediated ${ }^{86} \mathrm{Rb}^{+}$influx, 4-AP in combination with $\mathrm{Ba}^{2+}$ was applied and relative ${ }^{86} \mathrm{Rb}^{+}$uptake determined in the presence of the drugs. ${ }^{86} \mathrm{Rb}^{+}$uptake rates in the presence of these drugs were normalized to untreated control cells, and the results of all experiments obtained with the given drug were pooled and mean and SEM were plotted. $N$ values were, from left to right, $56,21,6,29,31,4,48,15$, 6 , and 4 . Effects that differed significantly from control as determined by ANOVA analysis: $* *, p<0.001$, Bonferroni $p$ value; $*, p<0.01$ from $t$ test, but Bonferroni $p$ values from ANOVA analysis were not significant because of smaller $N$ numbers. Ouabain and TTX inhibited ${ }^{86} \mathrm{Rb}^{+}$uptake in a dose-dependent manner. 4-AP $+\mathrm{Ba}^{2+}$ rcduced ${ }^{86} \mathrm{Rb}^{+}$ uptake by approximately $40 \%$, demonstrating that the residual TTXand ouabain-resistant influx is mediated by $\mathrm{K}^{+}$channels.

to the reduction observed by strophanthidin ( $p<0.001$ compared to control, $p=0.49$ compared to TTX, ANOVA Bonferroni corrected $p$ values). At lower TTX concentrations, TTX effects were smaller, and, in most experiments, $100 \mathrm{nM}$ TTX did not show any effect $(95 \pm 4 \%, N=31 ; p=0.54)$, as shown for one representative experiment in Figure 2 and for the mean of 31 experiments in Figure 3.

To investigate whether the effects of TTX and strophanthidin were mediated by separate pathways, or whether both effects were mediated by the $\mathrm{Na}^{+} / \mathrm{K}^{+}$-ATPase, we studied whether the effects were additive. The combined application of TTX and strophanthidin did not decrease ${ }^{86} \mathrm{Rb}^{+}$fluxes below the level observed with either one of the drugs alone (Fig. 2). This was also true for the combined application of $100 \mu \mathrm{M}$ TTX and 5 mM ouabain (Fig. 3), which resulted in an inhibition of ${ }^{86} \mathrm{Rb}^{+}$ influx of $64.3 \pm 6.4 \%(N=15)$ that did not differ significantly from application of TTX alone $(61 \pm 5.2 \%, N=48 ; p=0.74)$, 
suggesting that TTX and strophanthidin affected the same pathway for ${ }^{86} \mathrm{Rb}^{+}$entry, namely, the $\mathrm{Na}^{+} / \mathrm{K}^{+}$-ATPase.

Inhibition of ${ }^{86} \mathrm{Rb}^{+}$entry by TTX or strophanthidin was always incomplete, leaving $20-50 \%$ of influx (mean 39\%) unaccounted for. However, since ${ }^{86} \mathrm{Rb}^{+}$also permeates $\mathrm{K}^{+}$channels, it is likely that channcl-mediated ${ }^{86} \mathrm{Rb}^{+}$cntry can account for the residual ${ }^{86} \mathrm{Rb}^{+}$accumulation. Indeed, application of a cocktail known to block astrocyte $\mathrm{K}^{+}$channels ( $2 \mathrm{~mm}$ 4-AP in combination with $1 \mathrm{mM} \mathrm{Ba}^{2+}$ ) reduced ${ }^{86} \mathrm{Rb}^{+}$influx by $38.4 \pm 6.8 \%$, $N=6$ ), and combining the latter cocktail with ouabain resulted in an almost complete inhibition of ${ }^{86} \mathrm{Rb}^{+}$influx $(83.6 \pm 10.9 \%$, $N=4) . \mathrm{Na}^{+} / \mathrm{K}^{+} / 2 \mathrm{Cl}^{-}$transport has been demonstrated to be expressed in cultured cortical astrocytes (Kimelberg and Frangakis, 1985; Walz and Hinks, 1985), and this transporter would bc ablc to also account for ${ }^{86} \mathrm{Rb}^{+}$influx. Applying furoscmidc (1 $\mathrm{mm}$ ) or bumetanide $(0.1 \mathrm{~mm})$, which are commonly used inhibitors for $\mathrm{Na}^{+} / \mathrm{K}^{+} / 2 \mathrm{Cl}^{-}$uptake, resulted in variable but typically small ( $<20 \%$ of control) effects on ${ }^{86} \mathrm{Rb}^{+}$uptake, suggesting that indeed, $\mathrm{Na}^{+} / \mathrm{K}^{+}$-ATPase and $\mathrm{K}^{+}$channel-mediated diffusion represent the main entry pathways for ${ }^{86} \mathrm{Rb}^{+}$.

\section{C6 glioma and DRG cells}

To investigate whether the proposed relationship between $\mathrm{Na}^{+}$ influx through voltage-activated ion channels and $\mathrm{Na}^{+} / \mathrm{K}^{+}-$ ATPase activity is unique to astrocytes, or whether it is applicable more widely, we obtained ${ }^{86} \mathrm{Rb}^{+}$influx data like those described above, for $\mathrm{C} 6$ glioma cell lines and acutely dissociated DRG neurons. In our electrophysiological recordings we observed that cultured $\mathrm{C} 6$ glioma cells did not express detectable $\mathrm{Na}^{+}$channels, consistent with a previous report (Wang et al., 1992). In contrast to cultured astrocytes, $15 \mathrm{~min}$ of incubation of 66 glioma cells with $100 \mu \mathrm{M}$ TTX failed to alter the relative rate of ${ }^{86} \mathrm{Rb}^{+}$influx in these cell lines (Fig. 4; mean, $107.8 \pm$ $41.3 \%, N=5 ; p=0.8$ ). Acutely dissociated DRG neurons expressed both TTX-S and TTX-R voltage-activated $\mathrm{Na}^{+}$channels in our patch-clamp recordings (not shown), consistent with previous reports (Kostyuk et al., 1981; Caffrey et al., 1992; Roy and Narahashi 1992). However, as in C6 glioma cells, and unlike in astrocytes, incubation with $100 \mu \mathrm{M}$ TTX, which inhibited $\mathrm{Na}^{+}$currents in our electrophysiological recordings, did not alter ${ }^{86} \mathrm{Rb}^{+}$influx rates in these cells $(97.3 \pm 31.5 \%, N=4 ; p=0.97)$. Thus, the coupling between $\mathrm{Na}^{+}$channel-mediated $\mathrm{Na}^{+}$ion influx and $\mathrm{Na}^{+} / \mathrm{K}^{+}$-ATPase activity appears to be specific for astrocytes.

\section{Effect of TTX on astrocyte viability}

In all mammalian cells studied to date, the $\mathrm{Na}^{+} / \mathrm{K}^{+}-\mathrm{ATPase}$ contributes significantly in maintaining the ionic transmembrane gradients, and thus its function is essential for cell survival. The above results suggest that in spinal cord astrocytes $\mathrm{Na}^{+}$channels constitute a return pathway that is important for operation of ATPase. To assess how vital this " $\mathrm{Na}^{+}$return pathway" is for astrocytes, we asked whether astrocytes would tolerate chronic exposure to either TTX or strophanthidin. Cell survival was assayed by monitoring the cells' ability to exclude trypan blue, and the percentage of viable cells after a given drug exposure time was determined.

Inhibition of the astrocyte ATPase by $5 \mathrm{~mm}$ strophanthidin, and exposure of cells to TTX both lead to significant cell death. While untreated control cultures did not show evidence of significant cell death when monitored over a $2 \mathrm{hr}$ period, strophanthidin reduced the percentage of viable cells to $3.5 \%$ within

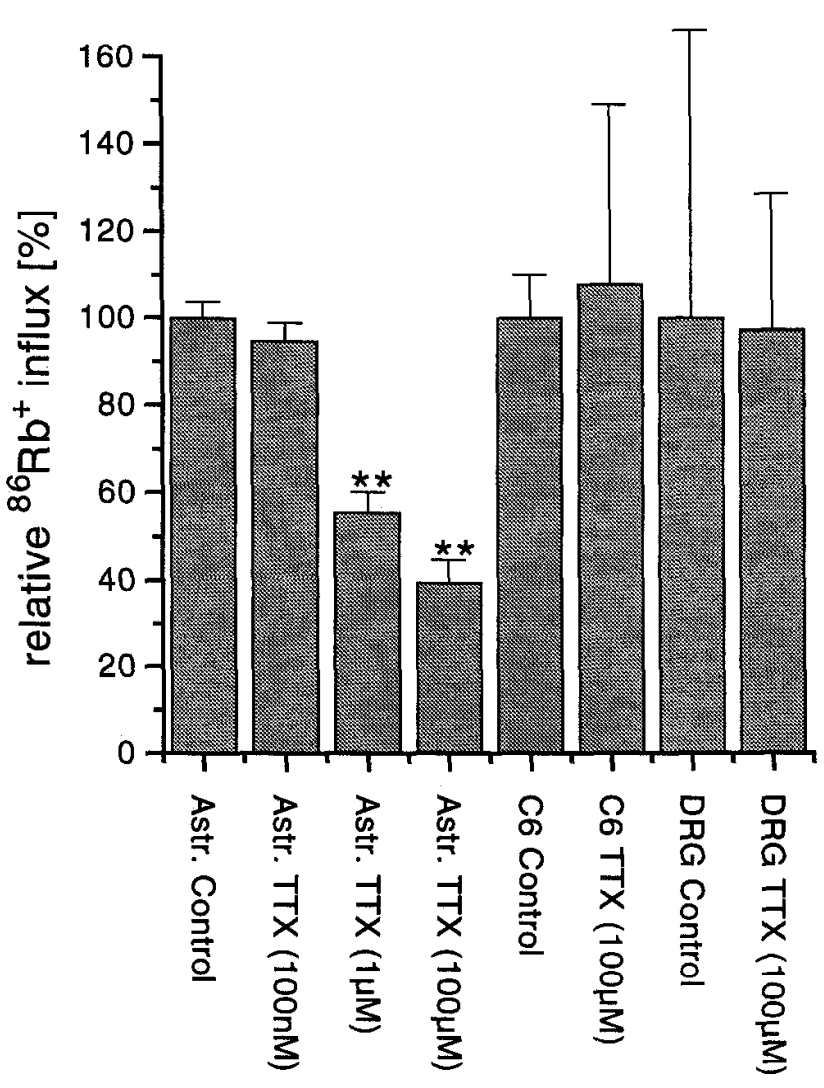

Figure 4. TTX reduction of ${ }^{86} \mathrm{Rb}^{+}$uptake is specific for astrocytes. ${ }^{86} \mathrm{Rb}^{+}$uptake was determined in cultures of rat spinal cord astrocytes, rat C6 glioma cell lines, and rat DRG neurons. Uptake was normalized to untreated control cells for the three preparations. TTX effects were significant only in astrocytes $(* *, p<0.01)$, whereas TTX effects did not alter ${ }^{86} \mathrm{Rb}^{+}$significantly in $\mathrm{C} 6$ glioma cells or DRG neurons.

60 min (Fig. 5). Exposure of cells to TTX had similar effects (Fig. 5), although the effectiveness of TTX was dependent on the concentration used (Fig. 6). Incubation with $10 \mu \mathrm{M}$ TTX reduced the percentage of viable cells to $54 \%$ within $60 \mathrm{~min}$ and only $19 \%$ of the cells survived after a 120 min treatment with $10 \mu_{\mathbf{M}}$ TTX (Fig. 5). Even larger effects were observed at 100 $\mu \mathrm{M}$ TTX, which reduced cell survival to $8.27 \%$ (Fig. 6). TTX effects were substantially smaller in $1 \mu \mathrm{M}$ TTX (87\% viable at $60 \mathrm{~min}$ ), and $100 \mathrm{nM}$ TTX did not reduce cell viability significantly (Fig. $6 ; p=0.91$ ).

To assure the validity of the assay used to determine cell survival, we obtained additional experiments using a recently described cytotoxicity assay ("Live/Dead," Molecular Probes, Inc.) that utilizes fluorescence dyes to discriminate between live an dead cells. This assay identifics dead cells by a rcd fluorescent fluorophore ethidium homodimer, which is excluded from live cells. Viable cells are identified by a yellow-green (fluorescein) stain generated by the enzymatic hydrolysis of calcein-AM that only occurs in live cells as a result of esterase activity. Results from those studies are straightforward to monitor, as cells light up differentially under the fluorescence microscope as yellow (=live) or red (=dead) cells. Representative examples of cells studied with this assay are illustrated in Figure 7 . Untreated control cells typically showed $>98 \%$ live (yellow) cells (Fig. $7 a$ ). By contrast, astrocytes treated with $100 \mu \mathrm{M}$ TTX for $60 \mathrm{~min}$ showed substantial numbers of dead (red) celis (Fig. $7 \mathrm{~h}$ ), as 


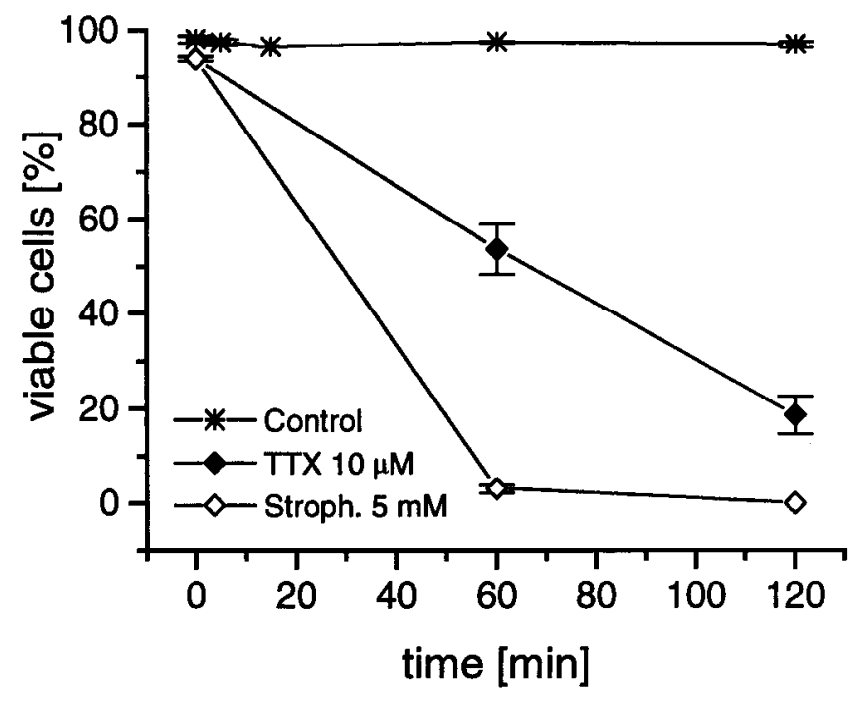

Figure 5. Reduced astrocyte viability in TTX and strophanthidin. Cell viability was assayed by determining the percentage of cells that maintained the ability to exclude trypan-blue. Cells were incubated for up to $2 \mathrm{hr}$ in various concentrations of TTX and strophanthidin: 10 randomly selected cell samples for each drug (cell number range, 55-285 cells) were counted at 5,60, and $120 \mathrm{~min}$ and the percentage of viable cells determined.

similarly observed in astrocytes treated with $5 \mathrm{~mm}$ ouabain (Fig. $7 c$ ). In contrast to these effects of TTX on astrocyte survival, neither DRG neurons nor C6 glioma cells were significantly affected by identical treatment with $100 \mu \mathrm{M}$ TTX.

These cell survival experiments demonstrate that fluxes of $\mathrm{Na}^{+}$ions through TTX inhibitable $\mathrm{Na}^{+}$channels are essential for the survival of a significant percentage of spinal cord astrocytes in culture, and further support the hypothesis that these channels, in astrocytes, provide a vital return pathway for $\mathrm{Na}^{+} /$ $\mathrm{K}^{+}$-ATPase function.

\section{Recording of $\left[\mathrm{Na}^{+}\right]_{\mathrm{i}}$ by quantitative fluorescence ratio imaging}

As the coupling of $\mathrm{Na}^{+}$channels to ATPase function can only be mediated by $\left[\mathrm{Na}^{+}\right]_{i}$, we expected that $\left[\mathrm{Na}^{+}\right]_{i}$ would decrease following $\mathrm{Na}^{+}$channel inhibition by TTX, which in turn would result in a depletion of $\mathrm{Na}^{+}$as substrate for ATPase function. To test whether this was indeed the case, we used the $\mathrm{Na}^{+}$sensitive ratiometric indicator SBFI to determine by quantitative digital ratio imaging whether $\left[\mathrm{Na}^{+}\right]_{i}$ in astrocytes changes in response to TTX. Superfusion of TTX $(100 \mu \mathrm{M})$ in most cells ( 9 of 12) resulted in a reversible decrease in the $340: 385 \mathrm{~nm}$ ratio indicating a decrease in $\left[\mathrm{Na}^{+}\right]_{i}$ (Fig. 8). Due to the high concentrations needed for $\mathrm{Na}^{+}$channel block and since bleaching of SBFI did not allow studies in excess of 20-30 min, we were limited to a 10 min TTX challenge. However, in all instances where TTX was effective, the 340:385 ratio was still declining after $10 \mathrm{~min}$ of TTX exposure and prior to the switch back to control solution. We compared TTX effects to the decrease of $\left[\mathrm{Na}^{+}\right]_{i}$ following incubation with $\mathrm{Na}^{+}$-free saline, which in other cell types was shown to deplete $\left[\mathrm{Na}^{+}\right]_{i}$ completely within minutes (Negulescu et al., 1990). $\mathrm{Na}^{+}$-free saline reversibly decreased the 340:385 ratio signal in all cells tested (12 of 12; Fig. 8 ). This effect was more rapid and its magnitude always exceeded the effects of TTX. To achieve some indication as to absolute $\mathrm{Na}^{+}$concentrations, we attempted to calibrate our recordings by application of $10 \mathrm{~mm} \mathrm{Na}{ }^{+}$-saline in the presence of the

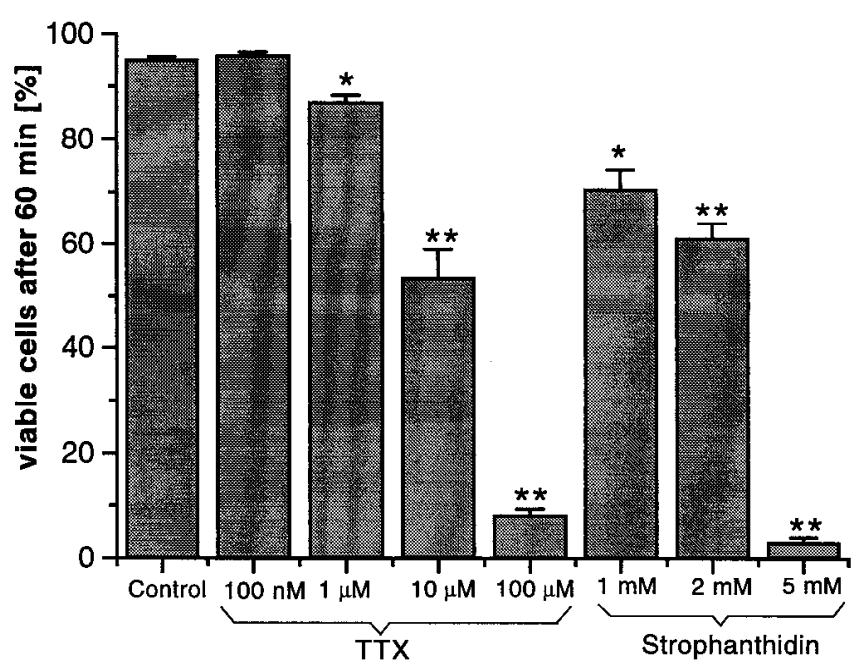

Figure 6. TTX and strophanthidin induce astrocyte death in a dosedependent manner. Cell viability, as assayed by cells' ability to exclude trypan blue, was determined after $60 \mathrm{~min}$ incubation with TTX or strophanthidin at the concentrations indicated (significant changes: *, $p$ $<0.05 ; * *, p<0.01$ )

ionophore gramidicidin $(5 \mu \mathrm{M})$ at the end of every experiment. Unfortunately, cells did not tolerate the ionophore well and SBFI bleached rapidly, and thus we were not able to obtain more complete calibration. Thus, to quantify effects of TTX on $\left[\mathrm{Na}^{+}\right]_{l}$, we determined the relative decrease in 340:385 ratios in the presence of TTX and in the presence of $\mathrm{Na}^{+}$-free saline. TTX effects after $10 \mathrm{~min}$ were $31.6 \%$ (SD $5.6 \%, N=9$ ) of those in $\mathrm{Na}^{+}$-free solution. Assuming that in $\mathrm{Na}^{+}$-free solution $\left[\mathrm{Na}^{+}\right]_{i}$ approached 0 (Negulescu et al., 1990), and assuming that the endpoint calibration with $10 \mathrm{mM} \mathrm{Na}{ }^{+}$reflected a true calibration value, and furthermore assuming a linear relationship for 340 : 385 ratios over the concentration rangc studied $(0-15 \mathrm{~mm}$; $\mathrm{Ne}$ gulescu et al., 1990), recordings were calibrated to absolute concentration values. Resting $\left[\mathrm{Na}^{+}\right]_{i}$ was thus determined to be $10.1 \mathrm{~mm}$ (SD 3.6, $N=12$ ) and TTX within $10 \mathrm{~min}$ dropped $\left[\mathrm{Na}^{+}\right]_{i}$ by $4 \mathrm{~mm}$ (SD 2.5, $N=9$ ), suggesting a rate of $0.4 \mathrm{~mm} /$ min. While these absolute values may be flawed by the limitations to our calibration procedures and depend on the assumptions made above, the qualitative change of $\left[\mathrm{Na}^{\prime}\right]_{i}$ clearly demonstrates that TTX results in a drop in $\left[\mathrm{Na}^{+}\right]_{i}$.

\section{Discussion}

The data presented here provide evidence for the existence of a small resting $\mathrm{Na}^{+}$conductance in spinal cord astrocytes that can be abolished by $100 \mu \mathrm{M}$ TTX. Since blockade of $\mathrm{Na}^{+}$channels not only depolarized the cells, but also significantly reduced ATPase activity as measured by unidirectional ouabain-sensitive influx of ${ }^{8} \mathrm{Rb}^{+}$, and reduced $\left[\mathrm{Na}^{+}\right]_{i}$, our results suggest that channel-mediated $\mathrm{Na}^{+}$entry and $\mathrm{Na}^{+} / \mathrm{K}^{+}$-ATPase activity are functionally interdependent.

Based on our observations, we suggest the following model to explain the coupling of $\mathrm{Na}^{+}$channel-mediated $\mathrm{Na}^{+}$fluxes and $\mathrm{Na}^{+} / \mathrm{K}^{+}-\mathrm{A}$ IPase (Fig. 9): a small, but finite open probability exists for astrocyte $\mathrm{Na}^{+}$channels at the resting potential [both $m_{\infty}$ and $h_{\infty}$ arc $>0$ (Sontheimer and Waxman, 1992)], leading to a small, steady influx of $\mathrm{Na}^{+}$ions that follow the electrochemical gradient. This influx of $\mathrm{Na}^{+}$ions is sufficient to maintain cytoplasmic $\mathrm{Na}^{+}$at concentrations required to 

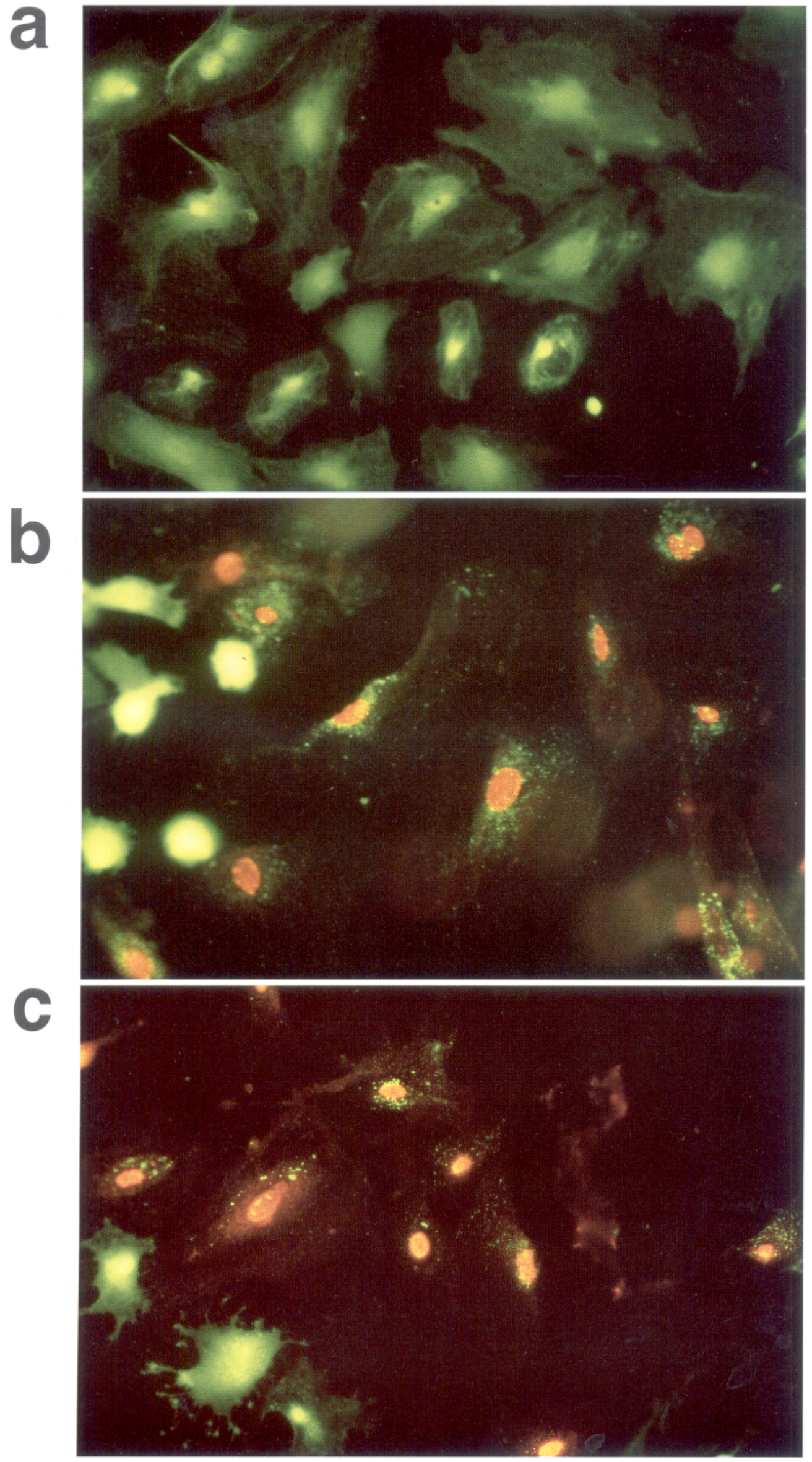

Figure 7. Astrocyte viability studied using calcein-AM/ethidium homodimer ("Live/Dead") cytotoxicity assay. Cells were treated with two fluorophores that selectively distinguish live (yellow) and dead (red) cells. Untreated cells incubated for $30 \mathrm{~min}$ with fluorophores did not contain dead cells $(a)$. By contrast, cells treated in addition with $100 \mu \mathrm{M}$ TTX $(b)$ or 5 mм ouabain (c) showed a significant number of dead (red) cells. 


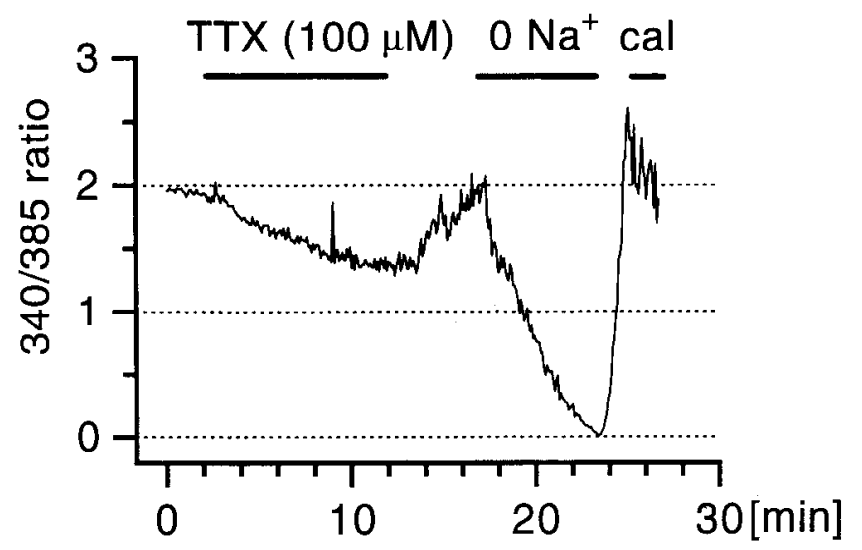

Figure 8. Ratiometric measurements of $\left[\mathrm{Na}^{+}\right]_{i}$ using SBFI. The relative $340: 385 \mathrm{~nm}$ ratio of SBFI fluorescence was obtained from cells loaded with the $\mathrm{Na}^{+}$-sensitive dye SBFI as described in Materials and Methods. Application of TTX resulted in a significant and reversible decrease in the 340:385 ratio, indicating a drop of $\left[\mathrm{Na}^{+}\right]_{i}$. Changing the bath solution to an $\mathrm{Na}^{+}$-free solution resulted in a similar, although more pronounced, drop in $\left[\mathrm{Na}^{+}\right]_{i}$. Calibration with $10 \mathrm{~mm} \mathrm{Na}{ }^{+}$in the presence of the ionophore gramicidin $(c a l)$ indicated that resting $\left[\mathrm{Na}^{+}\right]_{i}$ in this ccll was close to $10 \mathrm{~mm}$.

maintain $\mathrm{Na}^{+} / \mathrm{K}^{+}$-ATPase activity. Studies on $\mathrm{Na}^{+} / \mathrm{K}^{+}$-ATPases from numerous tissues (Stein, 1986) including glial cells (Kettenmann et al., 1987) show that low micromolar concentrations of $\left[\mathrm{Na}^{+}\right]_{i}$ are required to allow the $\mathrm{Na}^{+} / \mathrm{K}^{+}$-ATPase to function, and it has been demonstrated that $\mathrm{Na}^{+} / \mathrm{K}^{+}-\Lambda \mathrm{TPase}$ activity in cultured astrocytes depends on $\left[\mathrm{Na}^{+}\right]_{i}$ (Walz and Hinks, 1986). A $K_{m}$ for $\left[\mathrm{Na}^{+}\right]$, of $10 \mathrm{~mm}$ has been shown for $\mathrm{Na}^{+} / \mathrm{K}^{+}$-ATPase activation in batch isolated glial cells $(\mathrm{Ki}-$ melberg et al., 1978). Blockage of $\mathrm{Na}^{+}$channels by TTX inhibits the replenishment of intracellular $\mathrm{Na}^{+}$ions, and through the continued operation of the $\mathrm{Na}^{+} / \mathrm{K}^{+}$-ATPase, $\left[\mathrm{Na}^{+}\right]_{i}$ is depleted. Our imaging data using the $\mathrm{Na}^{+}$-sensitive indicator SBFI indicate that within $10 \mathrm{~min}\left[\mathrm{Na}^{+}\right]_{i}$ is reduced by about $30-40 \%$ of control. $\left[\mathrm{Na}^{+}\right]_{\text {i }}$ continued to decline throughout the period of TTX application (Fig. 9), and as we were limited to relatively short TTX applications $(10 \mathrm{~min})$, we were not able to record long enough to see a complete depletion of $\left[\mathrm{Na}^{+}\right]_{i}$. However, from our data we extrapolated that complete depletion of $\left[\mathrm{Na}^{+}\right]$ would be expected after $20-40 \mathrm{~min}$. As a consequence, $\mathrm{Na}^{+} /$ $\mathrm{K}^{+}$-ATPase activity is reduced due to a lack of substrate. This is reflected in the reduction of unidirectional influx of ${ }^{86} \mathrm{Rb}^{+}$, which is a direct measure of $\mathrm{Na}^{+} / \mathrm{K}^{+}$-ATPase activity. Inhibition of the $\mathrm{Na}^{+} / \mathrm{K}^{+}$-ATPase by ouabain or strophanthidin, as expected, also leads to a reduction in $\mathrm{K}^{+}$influx associated with a slow depolarization. Ouabain-induced depolarizations have been reported in numerous cell types, and are consistent with 'he breakdown of the ionic gradients for $\mathrm{Na}^{+}$and $\mathrm{K}^{+}$ions in the absence of ATPase function. Ouabain inhibition of $\mathrm{Na}^{+}$ $\mathrm{K}^{+}$-ATPase in glial cells has previously been demonstrated (Kimelberg et al., 1979b; Tang et al., 1980; Hertz, 1986), and in cultured cortical astrocytes results in membrane depolarizations of magnitude and rate $[0.9 \mathrm{mV} / \mathrm{min}$ (Kimelberg et al., 1979b; Hertz, 1986); $1.2 \mathrm{mV} / \mathrm{min}$ (Harold and Walz, 1992)] similar to those that we observed in spinal cord astrocytes after exposure to TTX and strophanthidin.

The $\mathrm{Na}^{+}$influx through $\mathrm{Na}^{+}$channels is small and does not always contribute significantly to the resting conductance. Whether the resting potential is influenced by TTX blockage

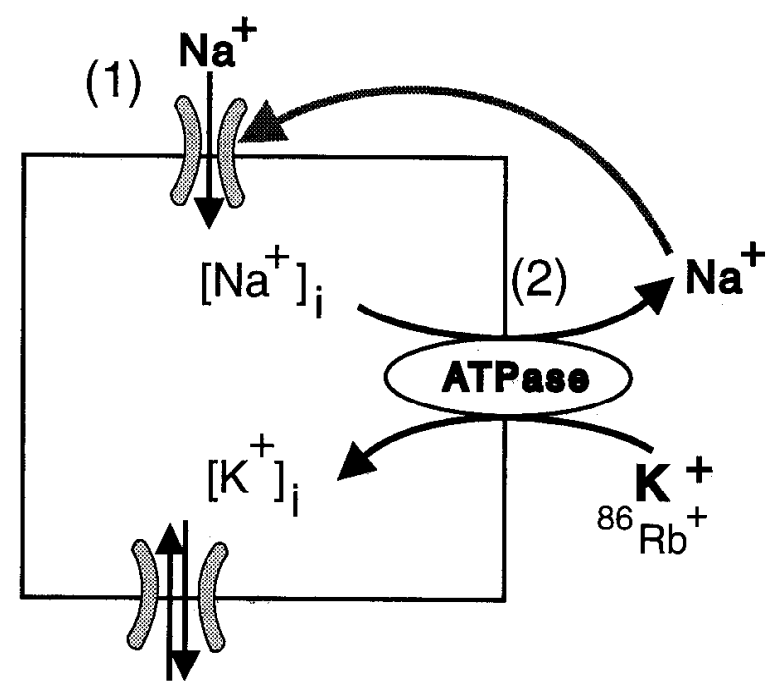

Figure 9. Simplified cell model to explain $\mathrm{Na}^{+}$channel- $\mathrm{Na}^{+} / \mathrm{K}^{+}-$ ATPase coupling in spinal cord astrocytes. $\mathrm{Na}^{+}$channels function to maintain intracellular $\left.\mathrm{Na}^{+}\left(\mathrm{Na}^{+}\right]_{1}\right)$ at levels that provide a substrate for $\mathrm{Na}^{+} / \mathrm{K}^{+}-$ATPase. TTX blocks $\mathrm{Na}^{+}$channels (1), while strophanthidin and ouabain interfere with activity of the ATPase (2).

depends on the relative contributions of $\mathrm{Na}^{+}$and $\mathrm{K}^{+}$conductance. If the $\mathrm{K}^{+}$conductance exceeds the $\mathrm{Na}^{+}$conductance by severalfold, as typically is the case for astrocytes (Sontheimer et al., 1991b, 1992; Sontheimer, 1992) blockage of the $\mathrm{Na}^{+}$ conductance would not be expected to alter the resting potential significantly, as observed in those cells that had $\mathrm{Na}^{+}$current densities of $<30 \mathrm{pA} / \mathrm{pF}$ (these cells did, however, display the slow depolarization presumably related to the breakdown of the ionic gradients following inhibition of the $\mathrm{Na}^{+} / \mathrm{K}^{+}$-ATPase). We only observed a contribution of resting $\mathrm{Na}^{+}$conductance to resting potential in those cells where $\mathrm{Na}^{+}$currents were expressed in high densities (typically $>50 \mathrm{pA} / \mathrm{pF}$ ).

The dependence of ATPase activity on $\mathrm{Na}^{+}$ion entry through TTX-inhibitable $\mathrm{Na}^{+}$channels is supported further by our observation that TTX exposure reduced astrocyte viability. Over $80 \%$ of astrocytes died during a $2 \mathrm{hr}$ exposure to TTX, strophanthidin, or ouabain. According to our proposed model, astrocyte death was caused as a consequence of the inhibition of ATPase activity by a lack of cytoplasmic $\mathrm{Na}^{+}$ions. Although we are not certain as to the cause of cell death, it is likely to be $\mathrm{Ca}^{2+}$ mediated. Voltage-dependent $\mathrm{Ca}^{2+}$ channels have becn described for cultured astrocytes (MacVicar, 1984; Barres et al., $1989 \mathrm{a}$ ), and these would be activated by the depolarization following the inhibition of the $\mathrm{Na}^{+} / \mathrm{K}^{+}$-ATPase. Strophanthidin and ouabain exerted their inhibitory effects directly on the pump; TTX, in contrast, acted by abolishing the $\mathrm{Na}^{+}$channel-mediated "return" flux of $\mathrm{Na}^{+}$ions necessary to maintain the $\left[\mathrm{Na}^{+}\right]_{i}$ substrate required for ATPase activity. These results are consistent with those of Ibata et al. (1971), who observed, using electron microscopy, glial cell injury following exposure to low$\mathrm{Na}^{+}$medium. Interestingly, TTX exposure has also been shown to reduce viability of cultured rat spinal cord neurons (Bergey et al., 1981) but failed to affect viability of cultured DRG neurons. In these studies, effects were most pronounced at early stages of in vitro development. TTX-induced neuronal death has been interpreted differently, and has led to the speculation that neurons require the ability to fire action potentials to survive in culture (Bergey et al., 1981). However, the interpretation 
suggested for spinal cord astrocytes here, namely, that $\mathrm{Na}^{+}$channels are important for $\mathrm{Na}^{+} / \mathrm{K}^{+}$-ATPase function, may also explain the observed neuronal cell death following chronic TTX treatment.

We included two additional cell preparations in our study: C6 glioma cell lines and DRG neurons. In both preparations, TTX was ineffective in inhibiting $\mathrm{Na}^{+} / \mathrm{K}^{+}-$ATPase as judged by ${ }^{86} \mathrm{Rb}^{+}$influx, whereas ouabain and strophanthidin, as expected, reduced ${ }^{86} \mathrm{Rb}^{+}$influx substantially. Since C6 glioma cells lack $\mathrm{Na}^{+}$channels (Wang et al., 1992), this observation was not surprising, and served as a control to exclude the possibility that TTX was affecting, in a less specific way, pathways other than $\mathrm{Na}^{+}$channels. The results obtained from DRG neurons are more intriguing. These cells express both TTX-S and TTX-R $\mathrm{Na}^{+}$channels (Kostyuk et al., 1981; Caffrey et al., 1992; Roy and Narahashi 1992). The inability of TTX to reduce ${ }^{86} \mathrm{Rb}^{+}$ influx rates in DRG neurons suggests that the proposed interdependence of $\mathrm{Na}^{+}$channel and ATPase function does not exist for DRG cells. Macroscopic $\mathrm{Na}^{+}$current properties in these neurons differ substantially from those observed in spinal cord astrocytes. Most notably, "window currents" are almost absent in DRG neurons, as $m_{\infty}$ and $h_{\infty}$ do not overlap significantly; thus, DRG neurons do not have a standing $\mathrm{Na}^{+}$conductance at rest (Roy and Narahashi 1992). Such a "standing" $\mathrm{Na}^{+}$conductance, however, is required by the proposed model, and its absence explains why a link between $\mathrm{Na}^{+}$channel activity and ATPase function is absent in these neurons. These results are also compatible with the previous observation that the viability of DRG neurons is not affected by chronic TTX treatment (Bergey et al., 1981).

The proposed model may still have more general applicability, and may explain the expression of voltage-activated $\mathrm{Na}^{+}$ channels in other nonexcitable cells, for example, Schwann cells (Chiu et al., 1984; Gray and Ritchie, 1985; Howe and Ritchie, 1990) or fibroblasts (Munson et al., 1979), where a functional role of $\mathrm{Na}^{+}$channels has not yet been defined.

Some astrocytes, approximately $20 \%$ of stellate and $15 \%$ of pancake cells did not display measurable $\mathrm{Na}^{+}$currents (resolution threshold $\sim 1 \mathrm{pA} / \mathrm{pF}$ ), and were able to maintain a stable resting potential in the presence or absence of TTX. We concluded that these cells lack a resting $\mathrm{Na}^{+}$conductance, at least one mediated by TTX-inhibitable, time- and voltage-dependent $\mathrm{Na}^{+}$channels. In vitro studies on other astrocyte preparations indicated that even larger percentages of astrocytes lack expression of voltage-activated $\mathrm{Na}^{+}$channels [mouse brain, $70 \%$ (Nowak et al., 1987); rat hippocampus, 50-60\% (Sontheimer et al., 1991b); rat optic nerve, 50-70\% (Barres et al., 1988; Sontheimer et al., 1991a)], and the percentage of cells that do express $\mathrm{Na}^{+}$channels decreases with time in vitro and in vivo (Minturn et al., 1991; Sontheimer et al., 1991a,b, 1992). In the absence of $\mathrm{Na}^{+}$channels, such cells must have other mechanisms that maintain $\left[\mathrm{Na}^{+}\right]$, at concentrations sufficient to support ATPase activity. Astrocytes can express numerous $\mathrm{Na}^{+}$-dependent ion carriers or cotransporters, for example, $\mathrm{Na}^{+} / \mathrm{HCO}_{3}+$ exchanger (Astion et al., 1989, 1991; Newman and Astion 1991), $\mathrm{Na}^{+} /$ Glu-cotransporter (Hertz, 1979; Brew and Attwell, 1987; Barbour et al., 1988; Nicholls and Attwell, 1990; Sarantis and Attwell, 1990), $\mathrm{Na}^{+} / \mathrm{KCl}^{-}$cotransport (Walz and Hinks 1986), and $\mathrm{Na}^{+} / \mathrm{H}^{+}$exchanger (Kimclberg, 1979; Kimelberg et al., 1979a; Walz and Hertz, 1984). Activity of these transporters would result in a net influx of $\mathrm{Na}^{+}$ions, and could provide a route for $\mathrm{Na}^{+}$influx sufficient to maintain ATPase activity. Walz and Hicks (1986) proposed an $\mathrm{Na}^{+}$cycle for cultured mouse cortical astrocytes where the $\mathrm{Na}^{+} / \mathrm{K}^{+}-\mathrm{ATPase}$ is fueled by $\mathrm{Na}^{+}$ ions entering by means of furosemide-sensitive $\mathrm{Na}^{+} / \mathrm{KCl}^{-}$cotransport. It is presently not known which $\mathrm{Na}^{+}$-dependent carriers or transporters are expressed in spinal cord astrocytes. We only observed small changes with application of furosemide or bumetanide, indicating that $\mathrm{Na}^{+} / \mathrm{KCl}^{-}$cotransport is weak. However, glutamate was highly potent in stimulating ${ }^{86} \mathrm{Rb}^{+}$ influx indicative of the presence of $\mathrm{Na}^{+}$-glutamate transporters (H. Sontheimer, unpublished observations). The latter, however, would not be effective as an $\mathrm{Na}^{+}$pathway under normal conditions in the absence of the neurotransmitter. $\mathrm{Na}^{+} / \mathrm{K}^{+}$ATPase activity would be thus dependent on $\mathrm{Na}^{+}$channels. The heterogeneity of astrocytes with respect to $\mathrm{Na}^{+}$channel density (Sontheimer, 1992) could represent a compensatory mechanism, ensuring the presence of a return pathway for $\mathrm{Na}^{+} / \mathrm{K}^{+}$. ATPase in cells that express varying densities of $\mathrm{Na}^{+}$-dependent ion carriers and cotransporters. Since our present study was limited to spinal cord astrocytes at $7-10 \mathrm{DIV}$, it is unclear whether the proposed relationship of $\mathrm{Na}^{+}$channcl priming of the $\mathrm{Na}^{+} / \mathrm{K}^{+}$-ATPase exists also in more mature astrocytes. It is possible that this mechanism is only functional during periods in which cells do not yet express other $\mathrm{Na}^{+}$dependent carriers at sufficient density. If true, this would explain the loss of $\mathrm{Na}^{+}$ channels in astrocytes cultured for prolonged periods.

Under physiological conditions, $\left[\mathrm{K}^{+}\right]_{o}$ is tightly regulated in the CNS to assure neuronal excitability, and one of the major functions of astrocytes in the CNS is believed to be the maintenance of this $\mathrm{K}^{+}$homeostasis (Kuffler et al., 1966; Orkand et al., 1966; Somjen, 1975; Orkand, 1977; Newman, 1986, 1993). $\mathrm{K}^{+}$ions that rapidly accumulate in the extracellular space following nerve activity are taken up by astrocytes via at least two independent mechanisms: (1) entrance into glial cells through $\mathrm{K}^{+}$ion channels (Newman 1984; Newman, 1986; Orkand, 1977; Orkand et al., 1966) and (2) $\mathrm{Na}^{+} / \mathrm{K}^{+}$-ATPase-mediated $\mathrm{K}^{+}$ uptake (Tang et al., 1980; Ballanyi et al., 1987). The latter mechanism, to operate effectively, requires a sufficient supply of intracellular $\mathrm{Na}^{+}$, and it has previously been shown that $\mathrm{Na}^{+}$/ $\mathrm{K}^{+}$-ATPase in astrocytes depends on and can be stimulated by increases in $\left[\mathrm{Na}^{+}\right]_{\mathrm{i}}$ (Walz and Hinks, 1986). In batch-isolated glial cells a $K_{m}$ for $\left[\mathrm{Na}^{+}\right]_{i}$ of $10 \mathrm{~mm}$ has been shown for $\mathrm{Na}^{+}$ $\mathrm{K}^{+}$-ATPase activation (Kimelberg et al., 1978), and thus, if [Na] is around $5-15 \mathrm{mM}$, as our SBFI imaging measurements indicate, then it is uniquely poised to activate the $\mathrm{Na}^{+} / \mathrm{K}^{+}-\mathrm{ATPase}$ maximally (see Kimelherg et al., 1993, for review). Since astrocyte membrane potential depends strongly on $\left[\mathrm{K}^{+}\right]_{o}$ (Kuffler et al., 1966; Orkand et al., 1966; Orkand, 1977) even small increases in $\left[\mathrm{K}^{+}\right]_{0}$ will depolarize astrocytes. Due to the resulting increased open probability of $\mathrm{Na}^{+}$channels (Sontheimer and Waxman, 1992), channel-mediated influx of $\mathrm{Na}^{+}$ions would be enhanced and would result in a stimulation of the $\mathrm{Na}^{+} / \mathrm{K}^{+}$. ATPase-mediated uptake of $\mathrm{K}^{+}$ions. Thus, the model proposed here for spinal cord astrocytes, which couples $\mathrm{Na}^{+}$channelmediated influx to $\mathrm{Na}^{+} / \mathrm{K}^{+}$-ATPase activity, would not only provide a vital pathway for $\mathrm{Na}^{+} / \mathrm{K}^{+}$-ATPase function under resting, steady-state conditions, but could also operate in a "feedback" manner to facilitate the $\mathrm{Na}^{+} / \mathrm{K}^{+}-\mathrm{AT}$ Pase-mediated removal of $\left[\mathrm{K}^{+}\right]_{o}$ following intense neuronal activity.

\section{References}

Astion ML, Chvatal A, Orkand RK (1989) $\mathrm{Na}^{+} / \mathrm{H}^{+}$exchange in glial cells of Necturus optic nerve. J Neurosci Lett 107:167-172. 
Astion ML, Chvatal A, Orkand RK (1991) Further studies of electrogenic $\mathrm{Na}^{+} / \mathrm{HCO}_{3}$-cotransport in glial cells of Necturus optic nerve: regulation of pHi. Glia 4:461 -468 .

Ballanyi K, Grafe P, TenBruggencate $G$ (1987) Ion activities and potassium uptake mechanisms of glial cells in guinea-pig olfactory cortex slices. J Physiol (Lond) 382:159-174.

Barbour B, Brew H, Attwell D (1988) Electrogenic glutamate uptake in glial cells is activated by intracellular potassium. Nature 335:433435.

Barres BA, Chun LLY, Corcy DP (1988) Ion channcl expression by white matter glia. I. Type 2 astrocytes and oligodendrocytes. Glia 1:10-30.

Barres BA, Chun LLY, Corey DP (1989a) Calcium current in cortical astrocytes: induction by cAMP and neurotransmitters and permissive effect of serum factors. J Neurosci 9:3169-3175.

Barres BA, Chun LLY, Corey DP (1989b) Glial and neuronal forms of the voltage-dependent sodium channel: characteristics and cell type distribution. Neuron 2:1375-1388.

Barres BA, Chun LLY, Corey DP (1990) Ion channels in vertebrate glia. Annu Rev Neurosci 13:441-474.

Bergey GK, Fitzgerald SC, Schrier BK, Nelson PG (1981) Neuronal maturation in mammalian cell cultures is dependent on spontaneous electrical activity. Brain Res 207:49-58.

Bevan S, Chiu SY, Gray PT $\Lambda$, Ritchie JM (1985) The presence of voltage-gated sodium, potassium and chloride channels in rat cultured astrocytes. Proc R Soc Lond [Biol] 225:299-313.

Black JA, Friedman B, Waxman SG, Elmer LW, Angelides KJ (1989) Immuno-ultrastructural localization of sodium channels at nodes of Ranvier and perinodal astrocytes in rat optic nerve. Proc R Soc Lond [Biol] 238:39-51.

Black JA, Sontheimer H, Waxman SG (1993) Spinal cord astrocytes in vitro: sodium channel immunoreactivity. Glia 7:272-285.

Brew H, Attwell D (1987) Electrogenic glutamate uptake is a major current carrier in the membrane of axolotl retinal glial cells. Nature 327:707-709.

Caffrey JM, Eng DL, Black JA, Waxman SG, Kocsis JD (1992) Three types of sodium channels in adult rat dorsal root ganglion neurons. Brain Res 592:283-297.

Chiu SY (1991) Functions and distribution of voltage-gated sodium and potassium channels in mammalian Schwann cells. Glia 4:541558.

Chiu SY, Schrager P, Ritchie JM (1984) Neuronal-type $\mathrm{Na}^{+}$and $\mathrm{K}^{+}$ channels in rabbit cultured Schwann cells. Nature 311:156-157.

Connors BW, Bernardo LS, Prince DA (1984) Carbon dioxide sensitivity of dye coupling among glia and neurons of the neocortex. $J$ Neurosci 4:1324-1330.

Dermietzel R, Hertzberg EL, Spray DC (1991) Gap junctions between cultured astrocytes: immunocytochemical, molecular, and electrophysiological analysis. J Neurosci 11:1421-1432.

Gautron S, Dossantos G, Pintohenrique D, Koulakoff A, Gros F, Berwald-Netter Y (1992) The glial voltage-gated sodium channel-cellspecific and tissue-specific messenger RNA expression. Proc Natl Acad Sci USA 89:7272-7276.

Goldschmidt RC, Kimelberg HK (1989) Protein analysis of mammalian cells in monolayer culture using the bicinchoninic assay. Anal Biochem 177:41-45.

Gray PTA, Ritchie JM (1985) Ion channels in Schwann and glial cells. Trends Neurosci 8:411-415.

Hamill OP, Marty A, Neher E, Sakmann B, Sigworth FJ (1981) Improved patch-clamp techniques for high-resolution current recording from cells and cell-free membrane patches. Pfluegers Arch 391:85100.

Harold DE, Walz W (1992) Metabolic inhibition and electrical properties of type-1-like cortical astrocytes. Neuroscience 47:203-211.

Harootunian A, Kao JPY, Ecker BK, Tsien RY (1989) Fluorescent ratio imaging of cytosolic free $\mathrm{Na}$ in individual fibroblasts and lymphocytes. J Biol Chem 264:19458-19467.

Hertz L (1979) Functional interactions between neurons and astrocytes. I. Turnover and metabolism of putative amino acid transmitters. Prog Neurosci 13:277-323.

Hertz L (1986) Potassium transport in astrocytes and neurons in primary cultures. Ann NY Acad Sci 481:318-333.

Hille B (1992) Ionic channels of excitable membranes. Sunderland, MA: Sinauer.

Howe JR, Ritchie JM (1990) Sodium currents in Schwann cells from myelinated and non-myelinated nerves of neonatal and adult rabbits. J Physiol (Lond) 425:169-210.

Ibata Y, Piccolio F, Pappas GD, Lajtha A (1971) An electron microscopic and biochemical study on the effect of cyanide and low $\mathrm{Na}^{+}$ on rat brain slices. Brain Res 30:137-158.

Kettenmann H, Ransom BR (1988) Electrical coupling between astrocytes and between oligodendrocytes in mammalian cell cultures. Glia 1:64-73.

Kettenmann H, Sykova E, Orkand RK, Schachner M (1987) Glial potassium uptake following depletion by intracellular iontophoresis. Pfluegers Arch 410:1-6.

Kimelberg HK (1979) Glial enzymes and ion transport. In: Neural trauma (Popp AJ, ed), pp 137-153. New York: Raven.

Kimelberg HK, Frangakis MV (1985) Furosemide- and bumetanidesensitive ion transport and volume control in primary cultures from rat brain. Brain Res 361:125-134.

Kimelberg HK, Mayhew E (1975) Increased ouabain-sensitive ${ }^{86} \mathrm{Rb}^{+}$ uptake and sodium and potassium ion-activated adenosine triphosphatase activity in transformed cell lines. J Biol Chem 250:100-104.

Kimelberg HK, Biddelcome S, Narumi S, Bourke RS (1978) ATPase and carbonic anhydrase activities of bulk-isolated neuron, glia and synaptosome fractions from rat brain. Brain Res 141:305-323.

Kimelberg HK, Biddlecome S, Bourke RS (1979a) SITS-inhibitable $\mathrm{Cl}^{-}$transport and $\mathrm{Na}^{+}$-dependent $\mathrm{H}^{+}$production in primary astroglial cultures. Brain Res 173:111-124.

Kimelberg HK, Bowman C, Biddlecome S, Bourke RS (1979b) Cation transport and membrane potential properties of primary astroglial cultures from neonatal rat brains. Brain Res 177:533-550.

Kimelberg HK, Jalonen T, Walz W (1993) Regulation of the brain microenvironment: transmitters and ions. In: Astrocytes, pharmacology and function (Murphy S, ed), pp 193-228. San Diego, CA Academic.

Kostyuk PG, Veselovsky NS, Tsyndrenko AY (1981) Ionic currents in the somatic membrane of rat dorsal root ganglion neurons. I. Sodium currents. Neurosci 6:2423-2430.

Kuffler SW, Nicholls JG, Orkand RK (1966) Physiological properties of glial cells in the central nervous system of amphibia. J Neurophysiol 29:768-787.

MacVicar BA (1984) Voltage-dependent calcium channels in glial cells. Science 226:1345-1347.

Miller RH, Szigeti V (1991) Clonal analysis of astrocyte diversity in neonatal rat spinal cord cultures. Development 113:353-362.

Minturn JE, Sontheimer H, Black JA, Angelides KJ, Ransom BR, Ritchie JM, Waxman SG (1991) Membrane-associated sodium channels and cytoplasmic precursors in glial cells: immunocytochemical electrophysiological and pharmacological studies. Ann NY Acad Sci 633:255-271.

Mobbs P, Brew H, Attwell D (1988) A quantitative analysis of glial cell coupling in the retina of the axolotl (Ambystoma mexicanum) Brain Res 460:235-245.

Moore PL, MacCoubrey RP, Haugland RP (1990) A rapid, pH insensitive, two color fluorescence viability (cytotoxicity) assay. J Cell Biol 111:58a.

Munson R Jr, Westermark B, Glaser L (1979) Tetrodotoxin-sensitive sodium channels in normal human fibroblasts and normal glia-like cells. Proc Natl Acad Sci USA 76:6425-6429.

Negulescu PA, Harootunian A, Tsien RY, Machen TE (1990) Fluorescence measurements of cytosolic free $\mathrm{Na}$ concentration, influx and efflux in gastric cells. Cell Regul 1:259-268.

Newman EA (1984) Regional specialisation of retinal glial cell membrane. Nature 309:155-157.

Newman EA (1986) High potassium conductance in astrocyte endfeet. Science 233:453-454.

Newman EA (1993) Inward-rectifying potassium channels in retinal glial (Müller) cells. J Neurosci 13:3333-3345.

Newman EA, Astion ML (1991) Localization and stoichiometry of electrogenic sodium bicarbonate cotransport in retinal glial cells. Glia $4: 424-428$.

Nicholls D, Attwell D (1990) The release and uptake of excitatory amino acids [see comments]. Trends Pharmacol Sci 11:462-468.

Nowak L, Ascher P, Berwald-Netter Y (1987) Ionic channels in mouse astrocytes in culture. $J$ Neurosci 7:101-109.

Orkand RK (1977) Glial cells. In: Handbook of physiology, The nervous system, Cellular biology of neurons (Brookhardt J, Mountcastle 
V, eds), pp 855-875. Washington, DC: American Physiological Society.

Orkand RK, Nicholls JG, Kuffler SW (1966) Effect of nerve impulses on the membrane potential of glial cells in the central nervous system of amphibia. J Neurophysiol 29:788-806.

Ransom BR, Goldring S (1973) Slow depolarization in cells presumed to be glia in cerebral cortex of cat. J Neurophysiol 36:869-878.

Ritchie JM (1992) Voltage-gated ion channels in Schwann cells and glia. Trends Neurosci 15:345-351.

Roy ML, Narahashi T (1992) Differential properties of tetrodotoxinsensitive and tetrodotoxin-resistant sodium channels in rat dorsal root ganglion neurons. J Neurosci 12:2104-2111.

Sarantis M, Attwell D (1990) Glutamate uptake in mammalian retinal glia is voltage- and potassium-dependent. Brain Res 516:322-325.

Smith PK, Krohn RI, Hermanson GT, Mallia AK, Gartner FH, Provenzano MD, Fujimoto EK, Goeke NM, Olson BJ, Klenk DC (1985) Measurement of protein using bicinchoninic acid. Anal Biochem 150: 76-85 [published erratum (1987), Anal Biochem 163:279].

Somjen GG (1975) Electrophysiology of neuroglia. Annu Rev Physiol 37:163-190.

Sontheimer H (1992) Astrocytes, as well as neurons, express a diversity of ion channels. Can J Physiol Pharmacol 70:s223-s238.

Sontheimer H, Waxman SG (1992) Ion channels in spinal cord astrocytes in vitro. II. Biophysical and pharmacological analysis of two $\mathrm{Na}^{+}$current types. J Neurophysiol 68:1001-1011.

Sontheimer H, Waxman SG (1993) Expression of voltage-activated ion channels by astrocytes and oligodendrocytes in the hippocampal slice. J Neurophysiol 70:1863-1873.

Sontheimer H, Minturn JE, Black JA, Ransom BR, Waxman SG (1991a) Two types of $\mathrm{Na}^{+}$-currents in cultured rat optic nerve astrocytes: changes with time in culture and with age of culture derivation. $J$ Neurosci Res 30:275-287.
Sontheimer H, Ransom BR, Cornell-Bell AH, Black JA, Waxman SG (1991b) $\mathrm{Na}^{+}$-current expression in rat hippocampal astrocytes in vitro: alterations during development. J Neurophysiol 65:3-19.

Sontheimer H, Black JA, Ransom BR, Waxman SG (1992a) Ion channels in spinal cord astrocytes in vitro. I. Transient expression of high levels of $\mathrm{Na}^{+}$and $\mathrm{K}^{+}$channels. J Neurophysiol 68:985-1000.

Sontheimer H, Ransom BR, Waxman SG (1992b) Different $\mathrm{Na}^{+}$currents from $\mathrm{P0}$ and $\mathrm{P} 7$-derived hippocampal astrocytes in vitro: evidence for a switch in $\mathrm{Na}^{+}$channel expression in vivo. Brain Res 597: 24-29.

Stein WD (1986) Transport and diffusion across cell membranes. San Diego: Academic.

Sweadncr KJ (1979) Two molecular forms of (Na' $\left.+\mathrm{K}^{\prime}\right)$-stimulated ATPase in brain. J Biol Chem 254:6060-6067.

Tang C-M, Cohen MW, Orkand RK (1980) Electrogenic pumps in axons and neuroglia and extracellular potassium homeostasis. Brain Res 194:283-286.

Walz W, Hertz L (1984) Sodium transport in astrocytes. J Neurosci Res 11:231-239.

Walz W, Hinks EC (1985) Carrier-mediated $\mathrm{KCl}$ accumulation accompanied by water movements is involved in the control of physiological $\mathrm{K}^{+}$levels by astrocytes. Brain Res 343:44-51.

Walz W, Hinks EC (1986) A transmembrane sodium cycle in astrocytes. Brain Res 368:226-232.

Walz W, MacVicar B (1988) Electrophysiological properties of glial cells: comparison of brain slices with primary cultures. Brain Res 443: 321-324.

Wang S-Y, Castle NA, Wang GK (1992) Identification of RBK1 potassium channels in C6 astrocytoma cells. Glia 5:146-153. 